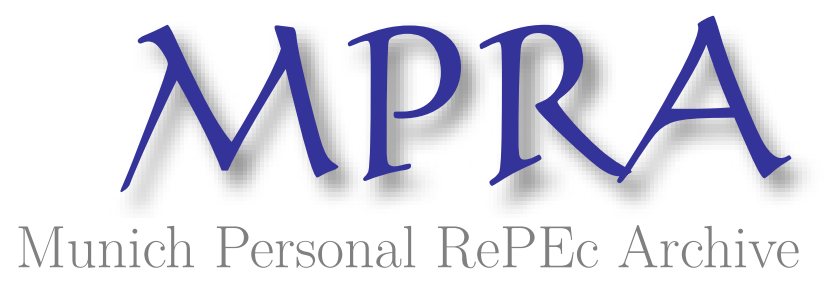

\title{
Impact of financial development on bank profitability
}

Ozili, Peterson K and Ndah, Honour

2022

Online at https://mpra.ub.uni-muenchen.de/111337/

MPRA Paper No. 111337, posted 02 Jan 2022 02:20 UTC 


\title{
Impact of financial development on bank profitability
}

\author{
Peterson K. Ozili, Central Bank of Nigeria; Nile University of Nigeria, Nigeria. \\ Honour Ndah, Nnamdi Azikiwe University, Nigeria.
}

\begin{abstract}
In this paper, we examine whether financial development is an important determinant of bank profitability. Using the robust ordinary least square and the generalized method of moments regression methodology, we find a significant negative relationship between the financial system deposits to GDP ratio and the non-interest income of Nigerian banks. This indicates that higher financial system deposits to GDP depresses the non-interest income of Nigerian banks. The result implies that the larger the size of the Nigerian financial system, the lower the profitability of banks in Nigeria. Also, we observe that bank concentration, nonperforming loans, cost efficiency and the level of inflation are significant determinants of the profitability of Nigerian banks.
\end{abstract}

Keywords: Bank profitability, financial development, banks, return on assets, return on equity, Nigeria, financial system, bank concentration, economic growth, size of financial system, domestic credit to private sector.

JEL Codes: G21, G18, O55, G28.

This version: January 2022 


\section{Introduction}

This paper investigates the effect of financial development on bank profitability. We examine whether financial development is an important determinant of bank profitability. Levine (2005) shows that financial development occurs when financial instruments, markets, and intermediaries ameliorate the effects of information cost, contract enforcement cost and transaction cost. Financial development can also be viewed in relation to the amount of transaction services provided by the financial system, and the ability of the financial system to channel funds through banks from depositors to investors for investment purposes (Ozili, 2019). Fitzgerald (2006) attributes the development of financial services to growth in the number of financial institutions, financial instruments and financial markets that support investment and economic growth process. In the literature, several indicators have been used to measure the level of financial development in a country, such as the ratio of credit to private sector to GDP, the ratio of broad money supply to GDP (Hajilee and Nasser, 2017), ratio of aggregate bank credit to GDP (Giuliano and RuizArranz, 2009; Ozili, 2019), ratio of foreign banks to total banks in a country (Ozili, 2017b, 2018b), availability of a local bank (Fafchamps and Schündeln, 2013), money supply as a percentage of GDP, liquidity ratio (Mesagan et al, 2018), size of the banking sector (Ting, 2017), and the ratio of stock market capitalization to GDP (Le and Ngo, 2020).

Banks are the most important contributors to financial system development in a country. They play an important role by providing financial intermediation through deposit mobilization, money transfer, settlement and lending to firms and households; thereby, stimulating economic growth and development (Levine, 1997; Guiso et al, 2004). When banks are profitable, they can invest in, or acquire, financial technology and sophisticated payment systems to help improve the financial intermediation process, thereby leading to high levels of financial development. In the absence of banks, there are few non-bank financial institutions that can perform significant financial intermediation activities, and the limited supply of non-bank funds may further reinforce the importance of banks in fostering financial development; therefore, the banking sector is crucial for the economic well-being of a country.

The level of financial development also plays an important role in improving the effectiveness of the financial system infrastructure in a country. In financially developed economies, high levels of 
financial development promote the smooth working of payment systems, financial intermediation processes, and settlement systems through improved market inefficiency. On the other hand, low level of financial development is arguably one of the main reasons why the banking sectors of most developing countries incur high costs, have high market inefficiencies, and perform poorly (Nourzad, 2002). Therefore, it is not surprising that bank supervisors in developing countries, in addition to monitoring bank capital and liquidity, often pay special attention to financial sector development. When financial systems are well-developed, there will be efficient allocation of credit to deficit units, and there will be substantial reduction in the cost of financial intermediation which would encourage economic agents to use bank credit for the production of goods and services (De Gregorio and Guidotti, 1995).

We are particularly interested in the case of Nigeria because Nigerian banks operate in a challenging high-cost business environment which hinders the pace of financial development, and has negative implications for banks' profit. Also, the most notable change in the banking sector was the forced bank mergers and acquisitions that occurred during the bank recapitalization and consolidation era between 2004 to 2005. These changes were part of the efforts to increase the level of financial development in Nigeria, and it is yet to be known whether improvements in the level of financial development can potentially increase bank profitability in Nigeria.

Many studies have examined the link between bank performance and financial development in developed countries (e.g. Murinde, 2012; Akimov et al, 2009). However, there is little knowledge in the literature about the effect of financial development on bank performance in developing countries especially in African countries. Presently, only few studies investigate the direct link between financial development and bank performance. We differentiate our study from previous African studies in the literature such as Effiong (2015), Ozili (2018b), and Dwumfour and NtowGyamfi (2018). These studies focus primarily on institutional factors such as legal origin, investor protection, and other institutional factors. Meanwhile, our studies focus more directly on how financial development affects bank profitability in Nigeria. Evidence on how financial development affects the profitability of the banking sector in African countries is scarce in the literature, and is completely absent for Nigeria. To the best of our knowledge, we are the first to provide evidence for the effect of financial development on bank profitability in Nigeria. 
To investigate the impact of financial development on banking sector profitability in Nigeria, we first use the OLS estimation as the baseline methodology. Thereafter, we use the first-difference GMM estimation and the two-stage OLS estimation methods for robustness purposes. The findings reveal an inverse relationship between the size of the financial system and bank profitability. Specifically, we observe that a high financial system deposits to GDP ratio is associated with low non-interest income for banks in Nigeria.

Our study contributes to the literature in several ways. Firstly, this study contributes to the literature that examine the relationship between financial development and bank profitability in other contexts (e.g., Demirgüç-Kunt and Huizinga, 2001; Klein and Weill, 2018; Le and Ngo, 2020). By focusing on banks, our analyses provide insights on how different levels of financial development affect bank profitability. We show that high levels of financial development can decrease the non-interest income and increase lending to deposit spread of banks depending on how financial development is measured. This insight gained can improve our understanding of which aspects of financial development improves bank profitability. Secondly, our analyses contribute to the rich literature that investigate the impact of financial development on firm performance (see, for example, Fafchamps and Schündeln, 2013; Dabla-Norris et al, 2012). Thirdly, our study contributes to the bank profitability determinants literature, by exploring how different measures of bank profit such as return on asset, return on equity, lending to deposit spread, and net interest income, are affected by external determinants of bank profitability (e.g., Lee and Hsieh, 2013; Ozili and Uadiale, 2017). By investigating a developing country context, we show that only the non-interest income is significantly affected by the level of financial development in Nigeria. Finally, in contrast to prior Nigerian studies (e.g. Mesagan et al, 2018; Adeniyi et al, 2015), we investigate Nigerian banks and use two unique indicators of financial development - an approach that has not being adopted by previous studies. This is the novelty of our study, and is also our main contribution to the literature on the effect of financial development on bank profitability in developing countries.

The rest of the paper is organized as follows. Section 2 presents the literature review and hypothesis development. Section 3 presents the data and methodology including the data sources and variables justification. Section 4 analyzes and discusses the results. Section 5 concludes. 


\section{Literature review and hypothesis development}

\subsection{Literature review}

Profitability in the banking sector is important for business continuity, bank stability and for economic growth. There are several measures of profitability in the banking literature, such as return on asset, return on equity, equity per share, non-interest income and net interest margin (Lee and Hsieh, 2013; Ozili and Uadiale, 2017). Non-interest income is an important measure of bank profitability. The size of bank's non-interest income is affected by bank specialization (Lee et al, 2014), the business model of the bank (Köhler, 2014), and bank's risk level (Williams, 2016). Lee et al (2014) examine the impact of non-interest income activities on bank risk and profitability, and find that non-interest activities reduce bank risk but do not increase profitability in a significant way. Also, they observe that bank specialization and country's income level increases non-interest activities.

The determinants of bank profitability in the literature are diverse. They are divided into two broad categories: the bank-specific determinants and macroeconomic determinants (Dietrich and Wanzenried, 2011; Bolt et al, 2012; Bikker and Vervliet, 2018). Other studies introduce additional profitability determinants such as financial structure and institutional factors (Demirgüç-Kunt and Huizinga, 2001; Ozili, 2019). In this study, we introduce financial development as a determinant of bank profitability. Bolt et al (2012) examine the relationship between bank profitability and the economic cycle. They argue that bank profits tend to be higher during economic booms and bank profits tend to be lower during economic recessions, implying that bank profits are pro-cyclical with fluctuating economic cycles. The result from their analyses show that the pro-cyclicality of bank profits is stronger during deep recessions than during mild recession. But Bolt et al (2012) did not use non-interest income as a measure of bank profitability and did not take into account the effect of financial development on bank profitability. Ahamed (2017) investigates whether a shift to non-interest income activities improved the profitability of banks in India. The findings reveal that higher non-interest income yields higher risk-adjusted profits particularly when banks are involved in more trading activities. Also, the findings reveal that income diversification benefits banks that have high non-performing loans compared to banks that have fewer nonperforming loans in India. But Ahamed (2017) did not take into account the effect of financial 
development on bank profitability. Zheng et al (2017) examine the effect of bank capital requirements on the cost of financial intermediation and bank profitability. They examine 32 banks in Bangladesh from 2000 to 2015. They find that higher bank regulatory capital ratio and higher cost efficiency ratio reduces the cost of financial intermediation and increase bank profitability, and the results are consistent when they used the equity to total asset ratio as an alternative measure of bank capital. But Zheng et al (2017) did not use non-interest income as a measure of bank profitability and did not take into account the effect of financial development on bank profitability. Borio et al (2017) investigate the impact of monetary policy on bank profitability using data for 109 large international banks headquartered in 14 major advanced economies from 1995 to 2012. They find a positive relationship between short-term interest rates and the interest rate structure and return on assets. The study by Borio et al (2017) did not take into account the effect of financial development on bank profitability. In a cross-study study, Ozili (2019) investigates the influence of financial development on banking sector performance. Bank performance was measured using the level of nonperforming loans. The findings reveal that nonperforming loans are positively correlated with profitability when profitability is measured using non-interest income. Also, the findings show that two financial development indicators, foreign bank presence and extent of financial intermediation, are positively associated with non-performing loans. The study by Ozili (2019) did not take into account the size of the financial sector as an indicator of financial development. Kumar and Bird (2021) investigate the factors influencing the profitability of banks in India and China. They find that credit quality, bank size, and cost management are determinants of bank profitability in India and China. But the study by Kumar and Bird (2021) did not use noninterest income as a measure of bank profitability. Ozili (2021) investigates the determinants of bank profitability in South Africa, Nigeria and the United States. The study finds that cost efficiency, the size of non-performing loans and overhead cost to total asset ratio are significant determinants of bank profitability. In South Africa, cost efficiency ratio, overhead cost to total asset ratio and non-performing loans are significant determinants of bank profitability. In the United States, capital adequacy ratio and the size of non-performing loans are significant determinants of bank profitability. In Nigeria, the overhead cost to total asset ratio and cost efficiency ratio are significant determinants of bank profitability. But the study by Ozili (2021) did not use non-interest income as a measure of bank profitability and did not take into account the effect of financial development on bank profitability. 
Some studies examine bank profitability in African countries. For instance, Ozili (2017a) investigates bank profitability determinants in Africa. The study finds that bank size, total regulatory capital and loan loss provisions are significant determinants of the return on assets of listed banks in Africa. Regulatory capital has a positive and significant impact on the return on assets of listed banks while higher regulatory capital thresholds have a negative impact on the return on asset of non-listed banks. But the study by Ozili (2017a) did not use non-interest income as a measure of bank profitability and did not take into account the effect of financial development on bank profitability. Oino (2015) analyses bank profitability determinants in sub-Saharan Africa from 2000 to 2012. The study finds that the cost to income ratio and capital ratio have a negative effect on bank profitability. The study also finds that the more diversified a bank is, the more profitable it is. But the study by Oino (2015) did not use non-interest income as a measure of bank profitability and did not take into account the effect of financial development on bank profitability. Anarfo and Appiahene (2017) investigate the determinants of bank profitability, focusing on the effect of capital structure on the profitability of banks in sub-Saharan Africa. They analyse 37 African countries, and measure capital structure using the debt ratio. They find that banks' capital structure, bank size, tangible asset and interest rate are significant determinants of bank profitability in sub-Saharan Africa. But the study by Anarfo and Appiahene (2017) did not take into account the effect of financial development on bank profitability. Banyen and Biekpe (2020) examine the effect of financial integration on bank profitability in five regional economic communities of Africa. They analyse 405 banks operating in 47 African countries from 2007 to 2014. They find a positive relationship between financial integration and bank profitability in Africa, except for the Arab Maghreb Union and the Southern Africa Development Community. But the study by Banyen and Biekpe (2020) did not take into account the effect of financial development on bank profitability.

Some studies examine bank profitability in Nigeria. Ebenezer et al (2017) examine the bankspecific and macroeconomic determinants of banks profitability from 2010 to 2015. Bank profitability was measured by return on assets and return on equity. They find that capital adequacy, liquidity and GDP growth have a positive and significant effect on bank profitability while the efficiency ratio has a negative and significant effect on bank profitability. But the study by Ebenezer et al (2017) did not use non-interest income as a measure of bank profitability and did not take into account the effect of financial development on bank profitability. Ozili and 
Uadiale (2017) investigate the impact of ownership concentration on bank profitability in Nigeria. Bank ownership concentration was measured as the amount of direct equity held by a majority shareholder categorised into: high ownership concentration, moderate ownership concentration and disperse ownership. They find that banks with high ownership concentration have higher return on assets, higher net interest margin and higher recurring earning power while banks with dispersed ownership have lower return on assets but have higher return on equity. But the study by Ozili and Uadiale (2017) did not use non-interest income as a measure of bank profitability and did not take into account the effect of financial development on bank profitability. Bolarinwa et al (2019) re-examine the determinants of bank profitability in Nigeria. They show that cost efficiency is a significant determinant of bank profitability in developing countries. But the study by Bolarinwa et al (2019) did not use non-interest income as a measure of bank profitability and did not take into account the effect of financial development on bank profitability in developing countries.

\subsection{Hypothesis development}

To develop the hypothesis, we draw on existing literature that investigate the effect of financial development on bank profitability. For instance, Demirguç-Kunt and Huizingha (2001) examine the impact of financial development and financial structure on bank profitability using bank level data for a large number of developed and developing countries over the 1990-1997 period. They find that financial development negatively affects bank performance because higher financial development will increase competition, and tougher competition will decrease bank profitability. Ting (2016) investigates the effects of financial development and government involvement in banks on bank profitability during the 2008 global financial crisis. The findings show that financial development and government involvement have positive effects on bank profitability during the 2008 global financial crisis, and the positive effect of financial development is stronger on banks with weak government involvement than on banks with strong government involvement. Le and Ngo (2020) investigate the determinants of bank profitability in 23 countries from 2002 to 2016. They use the ratio of stock market capitalization to GDP as a proxy for financial development. They find a positive relationship between capital market development and bank profitability.

We then argue that in countries with high level of financial development, banks can exploit the prevailing level of financial development to make substantial profits due to the presence of 
efficient financial markets, versatile financial instruments, and diverse counterparties. When banks make enough profit, they can re-invest some profit as retained earnings for business continuity purposes, and can use some portion of the profits to invest or acquire financial technology and systems to improve the efficiency of existing payment systems, financial services delivery, reducing market inefficiencies, thereby increase the level of financial development and contribute to higher bank profitability. Following this reasoning, we predict that banking sector profitability is directly associated with the prevailing level of financial development. Similarly, in countries with low level of financial development, banks may experience low profitability due to the presence of inefficient financial markets, few financial instruments, and non-diverse counterparties, thereby increasing market inefficiencies in the financial system, which would decrease bank profitability. Following this reasoning, we predict that banking sector profitability is positively related to the prevailing level of financial development.

\section{H1: the level of financial development is positively associated with banking sector profitability.}

In Nigeria, financial markets lack financial depth. There are only few institutional investors, many of which are unsophisticated investors, and the financial market is dominated by banks. The financial instruments in the Nigerian financial market are crude instruments such as commercial papers, letters of credit and IOUs, among others etc. Risk-sharing instruments and loss-sharing instruments such as exotic swaps, swaptions, and credit default swaps are non-existent in Nigerian financial markets because the financial markets in Nigeria are shallow compared to financial markets in developed countries. Also, financial institutions in Nigeria lend at high costs due to large information asymmetry between lenders and borrowers and the high cost of doing business in the country. The above-mentioned financial development issues would limit the ability of Nigerian banks to generate substantial profit. Therefore, we predict that low levels of financial development in Nigeria is associated with lower banking sector profitability, and vice versa. 


\section{Data and Methodology}

\subsection{Data}

Country data for Nigeria were collected from the global financial development indicators in the World Bank ${ }^{1}$ database. See Appendix 1. The data was collected for a 20-year period covering 1996 to 2016. In the data distribution, some country observations were missing for some years, which gives an unbalanced final sample. We used aggregated country-level data in the analyses rather than bank-level data for two reasons. Firstly, we had concerns that the link between financial development and bank balance sheet is rather indirect. This is because financial development may not have a direct impact on the balance sheet of banks. Our reasoning in this regard is guided by the literature which suggest that financial development has a more direct impact on the financial system and the infrastructure that banks rely on to operate in the environment, rather than on bank balance sheet. ${ }^{2}$ Given this understanding, we then used the World Bank country data for Nigeria's banking sector because we want to ensure that our analysis captures the direct effect of financial development on the profitability in the banking industry as a whole. And secondly, we used country level data in order to avoid some data issues relating to data double counting due to the bank mergers and acquisitions that occurred during the 2004 to 2005 bank recapitalization and consolidation era in Nigeria. The mergers and acquisitions exercise in Nigeria forced at least 10 banks to merge or close-down. The non-existence of at least 10 banks after the recapitalization and consolidation exercise would create data non-availability issues, and create data double counting issues for the merged or acquired banks category if we had used individual bank data for the analysis in the study.

\footnotetext{
${ }^{1}$ https://databank.worldbank.org/source/world-development-indicators

${ }^{2}$ Levine (2005)
} 


\subsection{Methodology}

\subsubsection{Model Specification}

The econometric specification of the model used in this study is a modified version of the model adopted in Demirguc-Kunt and Huizinga (2001), Ozili (2017a), Ozili and Uadiale (2017), and Le and Ngo (2020), and is expressed below:

$$
\pi t=c+C A R t+E F F t+N P L t+C N t+G D P t+C D t+F D t+I N F t \ldots \ldots \ldots 1
$$

Equation 1 shows the relationship between bank profitability and financial development while controlling for bank-specific and other determinants of bank profitability. $\pi$ is a vector of dependent variables. The dependent variables are five (5) profitability measures: after-tax return on asset (ROA), after-tax return on equity (ROE), net interest margin (NIM), non-interest income (NII), and bank lending to deposit spread (LD). For each dependent variable, the five separate models are specified and shown below;

$$
\begin{gathered}
\begin{array}{c}
R O A t=c+\beta 1 C A R t+\beta 2 E F F t+\beta 3 N P L t+\beta 4 C N t+\beta 5 G D P t+\beta 6 C D t+\beta 7 F D t \\
+\beta 8 I N F t \ldots \ldots \ldots 2
\end{array} \\
R O E t=c+\beta 1 C A R t+\beta 2 E F F t+\beta 3 N P L t+\beta 4 C N t+\beta 5 G D P t+\beta 6 C D t+\beta 7 F D t \\
+\beta 8 I N F t \ldots \ldots \ldots 3
\end{gathered}
$$

Where, $\mathrm{ROA}=$ after-tax return on assets; $\mathrm{ROE}=$ after-tax return on equity; $\mathrm{NII}=$ bank non-interest income to total income ratio; NIM = bank net interest margin; LD = bank lending-deposit spread; $\mathrm{EFF}=$ bank cost to income ratio; $\mathrm{CAR}=$ ratio of bank regulatory capital to risk-weighted assets; 
$\mathrm{NPL}=$ ratio of bank non-performing loans to gross loans; $\mathrm{CN}=$ bank concentration; $\mathrm{CD}=$ ratio of domestic credit to private sector to GDP; FD = ratio of financial system deposits to GDP; INF = inflation rate; GDP = real GDP growth .

\subsubsection{Variable Justification and Prediction}

For the dependent variable, we use three measures of bank profitability that are widely used in the literature namely ROA, ROE and NIM (see., Ozili and Uadiale, 2017; Bikker and Vervliet, 2018; Le and Ngo, 2020). We then introduce two additional measures of profitability: the non-interest income (NII) and bank lending to deposit spread (LD). These two additional profitability measures capture the business model of banks, thus, allowing us to test how financial development affects bank profitability that is linked to the business model of banks. More specifically, we introduce the 'lending to deposit spread' variable into the model as a measure of profitability because this variable reflects the profit-making (or business) model of banks since a major aspect of banking business involves managing the interest spread between deposits and loans ${ }^{3}$ (Valverde and Fernández, 2007). We also introduced the non-interest income variable into the model as a measure of profitability to account for the effect of financial development on banks' income diversification activities. This is because banks in well-developed financial systems tend to have greater opportunities to diversify their income stream, thus, leading to higher non-interest income (Ahamed, 2017), compared to developing countries.

For the explanatory variables, we use three bank-specific variables: the bank efficiency ratio (EFF), regulatory capital ratio (CAR), and the non-performing loans ratio (NPL). The EFF variable reflects bank efficiency, and is measured as the ratio of bank total cost to total income. The lower the ratio, the better. We expect a negative relationship between EFF and $\pi$ because efficient banks tend to be more profitable due to their ability to lower their total cost relative to total income (Olson and Zoubi, 2011; Ozili, 2017a; Le and Ngo, 2020).

The NPL variable reflects banks' asset quality, and is measured as the ratio of non-performing loan to gross loans. The lower the ratio, the better. We expect a negative relationship between NPL and $\pi$ because fewer loan default will improve bank profit (García-Herrero et al, 2009; Ozili, 2019).

\footnotetext{
${ }^{3}$ When the interest a bank earns on loans is greater than the interest it pays on deposits, the bank would generate income from the interest rate spread. The size of this spread is a major determinant of the profit generated by a bank.
} 
A low NPL ratio will lead to fewer loan loss provisions, which would increase banks' interest margin, and increase overall profitability (Ozili and Outa, 2017).

The CAR variable reflects regulatory capital ratio, which is the capital that banks need to set aside for the risks they take. The higher the regulatory capital, the better. We expect a positive relationship between CAR and $\pi$ because well-capitalized banks are more stable and are able to withstand unexpected losses compared to undercapitalized banks. This expectation is consistent with Lee and Hsieh (2013), Ozili (2017a) and Zheng et al (2017).

For the financial development variable, we use two variables to capture the level of financial development: financial system deposits to GDP ratio (FD), and the private domestic credit to GDP ratio $(\mathrm{CD})$ variables. These two variables have been used in the finance and growth literature to measure the level of financial development across countries (Klein and Weill, 2018; Beck et al, 2010; Adu et al, 2013; King and Levine, 1993).

The FD variable reflects the size of the financial system. It is measured as the ratio of financial system deposits to GDP. The bigger the ratio, the better. We expect a positive relationship between FD and $\pi$ because large financial systems tend to have greater capacity to absorb abnormal shocks to the financial system, and large financial systems tend to have a diverse number of financial institutions and instruments that facilitate loss-sharing and risk-sharing in order to reduce the impact of systemic losses on a single financial institution (Beck et al, 2010; Zhang et al, 2012; Peterson and Arun, 2018; Ozili, 2019).

The $\mathrm{CD}$ variable reflects domestic credit supply to the private sector. It is measured as the ratio of domestic credit to the private sector to GDP. The higher the ratio, the better. We expect a positive relationship between $\mathrm{CD}$ and $\pi$ because private credit given to borrowers by banks can be invested into profitable projects, and the interest income that banks earn from issuing private credit to profitable projects can improve bank profitability (Beck et al, 2010; Ayadi et al, 2015; Ozili, 2019).

The $\mathrm{CN}$ variable reflects bank concentration. We expect a positive relationship between $\mathrm{CN}$ and $\pi$ because, in highly concentrated banking sectors, dominant banks tend to have the highest profits due to their oligopolistic advantages in the market and the little competition they face. Dominant banks in highly concentrated environments tend to charge high interest on loans and high fees to borrowers who have few alternatives to obtain such financial services from elsewhere (see Dietrich 
and Wanzenried, 2011; Beck et al, 2006). Therefore, we expect higher profitability in a highly concentrated banking system.

For the macroeconomic variables, the GDP growth rate ( $\triangle \mathrm{GDP})$ variable reflects the state of the economy or the state of the business cycle. The higher the ratio, the better. We expect a positive relationship between $\Delta \mathrm{GDP}$ and $\pi$ because banks tend to be profitable during periods of economic prosperity, and tend to be less profitable during economic recessions (Bolt et al, 2012; Ozili and Outa, 2017). The INF variable reflects the rate of inflation. We expect a positive relationship between INF and $\pi$ because during inflationary periods, banks tend to increase the price of banking services and charge high interests on loans (above the inflation rate) in order to earn a higher profit margin. Therefore, banks tend to be profitable in inflationary periods (see., Tan and Floros, 2012).

\subsubsection{Estimation procedure}

Finally, the country-level data is time-series. The model is estimated using time-series ordinary least square (OLS) regression. For robustness purposes, we further estimate the OLS model using the Newey-West test to correct for autocorrelation and heteroscedasticity in the data distribution. We also use the general methods of moment (GMM) regression estimation method. The GMM method used in the study is the Arellano and Bond (1991) Generalized-Method-of Moments (GMM) first-difference estimator. The GMM first-difference estimator based on Arellano and Bond (1991) addresses three relevant econometric issues. One, the presence of unobserved bankspecific effects, which is eliminated by taking first-differences of all variables; two, the autoregressive process in the data regarding the behaviour of bank profitability (i.e., the need to use a lagged dependent variable(s) as an explanatory variable to capture the dynamic nature of bank profitability); and three, the likely endogeneity of the explanatory variables with the error term. The estimation results are reported in Section 4.2. 


\section{Empirical Results}

\subsection{Descriptive statistics and correlation}

Table 1 reports the descriptive statistics. Table 1 shows that the mean and median values of the profitability measures are approximately the same except for NIM and NII, while ROE has the largest standard deviation. Among the explanatory variables, the nonperforming loan (NPL) and bank concentration $(\mathrm{CN})$ variables have the highest standard deviation.

\begin{tabular}{|c|c|c|c|c|c|c|c|c|c|c|c|c|c|}
\hline \multicolumn{10}{|c|}{ Table 1: Descriptive Statistics } \\
\hline Statistics & ROA & ROE & NIM & NII & LD & INF & FD & CD & $\Delta$ GDP & CN & NPL & EFF & CAR \\
\hline Mean & 2.07 & 15.91 & 8.77 & 40.80 & 7.75 & 12.12 & 12.56 & 15.98 & 5.65 & 40.84 & 14.82 & 64.82 & 15.89 \\
\hline Median & 2.09 & 14.88 & 7.53 & 42.12 & 7.39 & 11.53 & 10.86 & 13.23 & 6.06 & 38.88 & 16.11 & 64.20 & 17.50 \\
\hline Maximum & 3.26 & 34.09 & 16.08 & 50.61 & 11.11 & 29.26 & 19.40 & 38.38 & 15.33 & 71.09 & 37.30 & 81.37 & 23.40 \\
\hline Minimum & 0.22 & 1.63 & 5.60 & 28.82 & 3.17 & 5.38 & 6.07 & 9.01 & -1.62 & 22.28 & 2.96 & 55.68 & 1.75 \\
\hline Std. Dev. & 0.79 & 7.26 & 2.59 & 6.34 & 1.99 & 5.37 & 4.72 & 7.39 & 3.42 & 14.71 & 9.66 & 6.25 & 5.48 \\
\hline Obs & 19 & 19 & 21 & 19 & 21 & 21 & 21 & 21 & 21 & 21 & 18 & 19 & 17 \\
\hline $\begin{array}{l}\text { Table } 3 \text { shows the descriptive statistics of all variables over the 19996 to 2016 period. Variable definition: ROA = after-tax return on assets; ROE = after-tax } \\
\text { return on equity; NII = bank noninterest income to total income ratio; NIM = bank net interest margin; LD = bank lending-deposit spread; EFF = bank cost to } \\
\text { income ratio; CAR = ratio of bank regulatory capital to risk-weighted assets; NPL = ratio of bank non-performing loans to gross loans; CN = bank concentration; } \\
\text { CD = ratio of domestic credit to private sector (\% of GDP); FD = ratio of financial system deposits to GDP; INF = inflation. }\end{array}$ \\
\hline
\end{tabular}

Table 2 presents the correlation table. We focus on the correlation between the profitability variables and the financial development variables. The 'FD' variable is significant and negatively correlated with NIM and NII which indicates that a large financial sector is correlated with lower profit margins and lower non-interest income for banks in Nigeria. The 'CD' variable is significant and negatively correlated with LD which indicates that higher domestic credit to private sector is associated with a lower lending-to-deposit spread for banks in Nigeria. Generally, the correlations in the Pearson correlation matrix are low. Also, the variance inflation factor (VIF) reported in the appendix show low correlations. Most of the variables in each model have a low centered VIF correlations as their centered VIF is less than 5 while only few variables have a centered VIF greater than 10 in each model. 
Table 2: Pearson Correlation

\begin{tabular}{|c|c|c|c|c|c|c|c|c|c|c|c|c|c|}
\hline Variables & ROA & ROE & NIM & NII & LD & INF & FD & $\mathrm{CD}$ & $\Delta \mathrm{GDP}$ & $\mathrm{CN}$ & NPL & EFF & CAR \\
\hline ROA & 1.00 & & & & & & & & & & & & \\
\hline ROE & $\begin{array}{c}0.82 * * * \\
(4.98)\end{array}$ & 1.00 & & & & & & & & & & & \\
\hline NIM & $\begin{array}{c}0.15 \\
(0.55)\end{array}$ & $\begin{array}{c}0.55 * * \\
(2.28)\end{array}$ & 1.00 & & & & & & & & & & \\
\hline NII & $\begin{array}{c}0.18 \\
(0.65)\end{array}$ & $\begin{array}{c}0.32 \\
(1.20)\end{array}$ & $\begin{array}{c}0.21 \\
(0.74)\end{array}$ & 1.00 & & & & & & & & & \\
\hline LD & $\begin{array}{c}-0.14 \\
(-0.51)\end{array}$ & $\begin{array}{c}-0.09 \\
(-0.32)\end{array}$ & $\begin{array}{c}-0.01 \\
(-0.02)\end{array}$ & $\begin{array}{c}-0.18 \\
(-0.65)\end{array}$ & 1.00 & & & & & & & & \\
\hline INF & $\begin{array}{c}0.25 \\
(0.91)\end{array}$ & $\begin{array}{c}0.39 \\
(1.49)\end{array}$ & $\begin{array}{c}0.33 \\
(1.22)\end{array}$ & $\begin{array}{c}-0.02 \\
(-0.07)\end{array}$ & $\begin{array}{c}-0.14 \\
(-0.50)\end{array}$ & 1.00 & & & & & & & \\
\hline FD & $\begin{array}{c}-0.02 \\
(-0.07)\end{array}$ & $\begin{array}{c}-0.35 \\
(-1.32)\end{array}$ & $\begin{array}{l}-0.49 * \\
(-1.97)\end{array}$ & $\begin{array}{c}-0.79 * * * \\
(-4.52)\end{array}$ & $\begin{array}{c}0.09 \\
(0.32)\end{array}$ & $\begin{array}{c}-0.05 \\
(-0.18)\end{array}$ & 1.00 & & & & & & \\
\hline $\mathrm{CD}$ & $\begin{array}{c}0.27 \\
(0.98)\end{array}$ & $\begin{array}{l}-0.001 \\
(-0.01)\end{array}$ & $\begin{array}{c}-0.36 \\
(-1.34)\end{array}$ & $\begin{array}{c}0.30 \\
(1.09)\end{array}$ & $\begin{array}{c}-0.58 * * \\
(-2.48)\end{array}$ & $\begin{array}{c}-0.08 \\
(-0.28)\end{array}$ & $\begin{array}{c}0.21 \\
(0.75)\end{array}$ & 1.00 & & & & & \\
\hline$\Delta \mathrm{GDP}$ & $\begin{array}{c}0.21 \\
(0.72)\end{array}$ & $\begin{array}{c}0.17 \\
(0.63)\end{array}$ & $\begin{array}{c}0.29 \\
(1.08)\end{array}$ & $\begin{array}{c}-0.21 \\
(-0.73)\end{array}$ & $\begin{array}{c}-0.22 \\
(-0.78)\end{array}$ & $\begin{array}{c}0.38 \\
(1.43)\end{array}$ & $\begin{array}{c}0.03 \\
(0.12)\end{array}$ & $\begin{array}{c}0.05 \\
(0.17)\end{array}$ & 1.00 & & & & \\
\hline $\mathrm{CN}$ & $\begin{array}{c}0.12 \\
(0.42)\end{array}$ & $\begin{array}{c}-0.35 \\
(-1.32)\end{array}$ & $\begin{array}{c}-0.68 * * * \\
(-3.26)\end{array}$ & $\begin{array}{c}-0.13 \\
(-0.47)\end{array}$ & $\begin{array}{c}-0.16 \\
(-0.57)\end{array}$ & $\begin{array}{c}-0.33 \\
(-1.21)\end{array}$ & $\begin{array}{c}0.58 * * \\
(2.50)\end{array}$ & $\begin{array}{c}0.66 * * * \\
(3.094)\end{array}$ & $\begin{array}{c}0.03 \\
(0.12)\end{array}$ & 1.00 & & & \\
\hline NPL & $\begin{array}{c}0.05 \\
(0.17)\end{array}$ & $\begin{array}{c}0.27 \\
(0.98)\end{array}$ & $\begin{array}{c}0.34 \\
(1.27)\end{array}$ & $\begin{array}{c}0.63 * * \\
(2.86)\end{array}$ & $\begin{array}{c}0.19 \\
(0.69)\end{array}$ & $\begin{array}{c}0.24 \\
(0.88)\end{array}$ & $\begin{array}{c}-0.82 * * * \\
(-5.12)\end{array}$ & $\begin{array}{c}-0.27 \\
(-0.98)\end{array}$ & $\begin{array}{c}0.07 \\
(0.24)\end{array}$ & $\begin{array}{c}-0.57 * * \\
(-2.44)\end{array}$ & 1.00 & & \\
\hline $\mathrm{EFF}$ & $\begin{array}{c}-0.37 \\
(-1.42)\end{array}$ & $\begin{array}{c}-0.54 * * \\
(-2.26)\end{array}$ & $\begin{array}{c}-0.35 \\
(-1.31)\end{array}$ & $\begin{array}{c}-0.37 \\
(-1.39)\end{array}$ & $\begin{array}{c}0.22 \\
(0.79)\end{array}$ & $\begin{array}{c}0.27 \\
(1.002)\end{array}$ & $\begin{array}{c}0.29 \\
(1.06)\end{array}$ & $\begin{array}{c}-0.26 \\
(-0.95)\end{array}$ & $\begin{array}{c}0.18 \\
(0.65)\end{array}$ & $\begin{array}{c}0.21 \\
(0.77)\end{array}$ & $\begin{array}{l}-0.015 \\
(-0.05)\end{array}$ & 1.00 & \\
\hline CAR & $\begin{array}{c}-0.18 \\
(-0.64)\end{array}$ & $\begin{array}{c}-0.02 \\
(-0.08)\end{array}$ & $\begin{array}{c}0.05 \\
(0.21)\end{array}$ & $\begin{array}{c}0.11 \\
(0.41)\end{array}$ & $\begin{array}{l}-0.53^{*} \\
(-2.17)\end{array}$ & $\begin{array}{l}-0.372 \\
(-1.38)\end{array}$ & $\begin{array}{l}-0.09 \\
(-0.32)\end{array}$ & $\begin{array}{c}0.37 \\
(1.41)\end{array}$ & $\begin{array}{c}-0.07 \\
(-0.26)\end{array}$ & $\begin{array}{c}0.15 \\
(0.54)\end{array}$ & $\begin{array}{c}-0.33 \\
(-1.22)\end{array}$ & $\begin{array}{l}-0.45 \\
(-1.76)\end{array}$ & 1.00 \\
\hline
\end{tabular}

This table reports the correlation matrix. T-statistics are reported in parenthesis. Variable description: ROA $=$ after-tax return on assets; ROE = after-tax return on equity; NII = bank noninterest income to total income ratio; NIM =bank net interest margin; $\mathrm{LD}=$ bank lending-deposit spread; $\mathrm{EFF}=$ bank cost to income ratio; CAR = ratio of bank regulatory capital to risk-weighted assets; NPL = ratio of bank non-performing loans to gross loans; $\mathrm{CN}=$ bank concentration; $\mathrm{CD}=$ ratio of domestic credit to private sector (\% of GDP); FD = ratio of financial system deposits to GDP; INF = inflation. 


\subsection{Regression Results}

The results are presented in the following order. First, we analyze the profitability determinants in the Nigerian banking sector taking into account only the bank-specific and macroeconomic profitability determinants. Next, we introduce the financial development variables, to determine the impact of the level of financial development on banking sector profitability. Next, we analyze the relationship between financial development and bank profitability in the post-financial crisis era. In the estimations, we report the results using two estimation techniques: the Newey-West HAC ordinary least square (OLS) regression estimation and the generalized method of moments (GMM) regression estimation. The results are considered to be robust if the coefficients remain significant and report similar coefficient signs in the two estimations. And finally, we estimate the results using the two-stage least square estimation.

\subsubsection{Bank profitability determinants}

The regression results are reported in table 3. The CAR coefficient is insignificant in all estimations except in Column 10 where the CAR coefficient is significant and negatively related to LD in the OLS estimation in column 10 but is insignificant in the corresponding GMM estimation in column 9. The mixed sign of the coefficient in the OLS and GMM estimations suggest that the result for CAR is not robust. Also, the insignificance of the CAR coefficient in the OLS and GMM estimations suggest that higher regulatory capital ratios did not significantly affect bank profitability in Nigeria. One explanation for this is that higher regulatory capital ratios possibly have two mixed effects on bank profitability in Nigeria in that higher regulatory capital ratios could tie down the capital that Nigerian banks could use to issue new loans at higher interest rates to improve their profitability, or could discourage Nigerian banks from taking excessive risk in their lending activities (Ozili, 2015). The EFF coefficient reports a negative sign as expected and is significantly related to ROE in columns 3 and 4. This result is consistent with Zheng et al (2017) and Ozili (2017a), and supports the prediction that efficient banks have higher profitability (Zheng et al, 2017; Ozili, 2017a). The NPL coefficient is positive and significantly related to NII in Column 7 and 8, implying that high non-performing loans leads to high non-interest income. One explanation for this is that Nigerian banks that expect high nonperforming loans increase their fees-generating activities in order to generate additional income to augment a shortfall in interest income arising from increasing nonperforming loans. This explanation is consistent with the 
profitability-diversification hypothesis of Smith et al (2003) who predict that banks will diversify into activities that generate non-interest income to augment expected shortfalls in interest income arising from rising nonperforming loans especially in a low interest rate banking environments (Smith et al, 2003; Bikker and Vervliet, 2018). The $\Delta$ GDP coefficient is insignificant in all estimations except in column 7 . The $\triangle$ GDP coefficient is significant and negatively related to NII in the GMM estimation in column 7 and is insignificant in the corresponding OLS estimation in column 8. The INF coefficient is positive and significantly related to ROE and NIM in columns 3 , 4, 5 and 6 respectively. This indicates that the Nigerian banking sector experience higher profitability during inflationary periods. This result is consistent with the findings of Tan and Floros (2012) who argue that banks will increase the price of banking services and charge high interest rate on loans - charging interest rates above the inflation rate - in order to earn a higher profit margin, thereby increasing bank profitability.

\begin{tabular}{|c|c|c|c|c|c|c|c|c|c|c|}
\hline \multicolumn{11}{|c|}{ Table 3: Bank profitability determinants (without the financial development indicators) } \\
\hline & \multicolumn{2}{|c|}{ Dependent variable: ROA } & \multicolumn{2}{|c|}{ Dependent variable: $\mathrm{ROE}$} & \multicolumn{2}{|c|}{ Dependent variable: NIM } & \multicolumn{2}{|c|}{ Dependent variable: NII } & \multicolumn{2}{|c|}{ Dependent variable: LD } \\
\hline & $(1)$ & (2) & (3) & (4) & (5) & (6) & (7) & (8) & (9) & (10) \\
\hline & GMM & OLS-HAC & GMM & OLS-HAC & GMM & OLS-HAC & GMM & OLS-HAC & GMM & OLS-HAC \\
\hline & $\begin{array}{l}\text { Coefficient } \\
\text { (t-statistic) }\end{array}$ & $\begin{array}{l}\text { Coefficient } \\
\text { (t-statistic) }\end{array}$ & $\begin{array}{l}\text { Coefficient } \\
\text { (t-statistic) }\end{array}$ & $\begin{array}{l}\text { Coefficient } \\
\text { (t-statistic) }\end{array}$ & $\begin{array}{l}\text { Coefficient } \\
\text { (t-statistic) }\end{array}$ & $\begin{array}{l}\text { Coefficient } \\
\text { (t-statistic) }\end{array}$ & $\begin{array}{l}\text { Coefficient } \\
\text { (t-statistic) }\end{array}$ & $\begin{array}{l}\text { Coefficient } \\
\text { (t-statistic) }\end{array}$ & $\begin{array}{l}\text { Coefficient } \\
\text { (t-statistic) }\end{array}$ & $\begin{array}{l}\text { Coefficient } \\
\text { (t-statistic) }\end{array}$ \\
\hline $\mathbf{C}$ & $\begin{array}{l}4.947 \\
(1.32)\end{array}$ & $\begin{array}{c}9.834^{* * *} \\
(2.67)\end{array}$ & $\begin{array}{c}79.67 * * \\
(2.85)\end{array}$ & $\begin{array}{c}81.44 * * * \\
(3.38)\end{array}$ & $\begin{array}{c}14.045^{*} \\
(1.87)\end{array}$ & $\begin{array}{l}15.057 \\
(1.79)\end{array}$ & $\begin{array}{c}49.163 * * * \\
(4.04)\end{array}$ & $\begin{array}{c}50.121^{* * *} \\
(2.66)\end{array}$ & $\begin{array}{c}16.982^{*} \\
(2.05)\end{array}$ & $\begin{array}{c}19.228^{*} \\
(2.25)\end{array}$ \\
\hline CAR & $\begin{array}{l}0.040 \\
(0.42)\end{array}$ & $\begin{array}{l}-0.076 \\
(-1.43)\end{array}$ & $\begin{array}{l}-0.685 \\
(-1.07)\end{array}$ & $\begin{array}{l}-0.254 \\
(-1.33)\end{array}$ & $\begin{array}{l}0.063 \\
(0.54)\end{array}$ & $\begin{array}{l}0.033 \\
(0.25)\end{array}$ & $\begin{array}{l}0.208 \\
(0.99)\end{array}$ & $\begin{array}{l}0.345 \\
(0.98)\end{array}$ & $\begin{array}{l}-0.197 \\
(-1.73)\end{array}$ & $\begin{array}{l}-0.260^{*} \\
(-2.24)\end{array}$ \\
\hline EFF & $\begin{array}{l}-0.067 \\
(-1.88)\end{array}$ & $\begin{array}{l}-0.111^{*} \\
(-2.11)\end{array}$ & $\begin{array}{c}-0.964 * * \\
(-3.06)\end{array}$ & $\begin{array}{c}-1.172^{* *} \\
(-3.12)\end{array}$ & $\begin{array}{l}-0.155 \\
(-1.71)\end{array}$ & $\begin{array}{l}-0.166 \\
(-1.69)\end{array}$ & $\begin{array}{c}-0.327^{*} \\
(-1.89)\end{array}$ & $\begin{array}{l}-0.357 \\
(-1.58)\end{array}$ & $\begin{array}{l}-0.064 \\
(-0.58)\end{array}$ & $\begin{array}{l}-0.077 \\
(-0.63)\end{array}$ \\
\hline NPL & $\begin{array}{l}-0.028 * \\
(-2.01)\end{array}$ & $\begin{array}{l}-0.018 \\
(-1.29)\end{array}$ & $\begin{array}{l}-0.019 \\
(-0.15)\end{array}$ & $\begin{array}{l}0.072 \\
(0.45)\end{array}$ & $\begin{array}{l}0.056^{*} \\
(1.98)\end{array}$ & $\begin{array}{l}0.058 \\
(1.50)\end{array}$ & $\begin{array}{c}0.484 * * * \\
(3.49)\end{array}$ & $\begin{array}{c}0.522 * * \\
(3.04)\end{array}$ & $\begin{array}{l}-0.005 \\
(-0.09)\end{array}$ & $\begin{array}{l}-0.028 \\
(-0.37)\end{array}$ \\
\hline$\Delta$ GDP & $\begin{array}{l}0.004 \\
(0.11)\end{array}$ & $\begin{array}{l}0.055 \\
(0.69)\end{array}$ & $\begin{array}{l}-0.026 \\
(-0.07)\end{array}$ & $\begin{array}{l}0.279 \\
(0.48)\end{array}$ & $\begin{array}{l}0.134 \\
(1.30)\end{array}$ & $\begin{array}{l}0.136 \\
(1.21)\end{array}$ & $\begin{array}{c}-0.650 * * \\
(-3.14)\end{array}$ & $\begin{array}{l}-0.425 \\
(-0.98)\end{array}$ & $\begin{array}{l}-0.081 \\
(-1.39)\end{array}$ & $\begin{array}{l}-0.113 \\
(-1.21)\end{array}$ \\
\hline INF & $\begin{array}{c}0.105^{* * *} \\
(2.78) \\
\end{array}$ & $\begin{array}{l}0.053 \\
(0.80) \\
\end{array}$ & $\begin{array}{c}1.064 * * \\
(2.77)\end{array}$ & $\begin{array}{l}1.019 * \\
(2.03)\end{array}$ & $\begin{array}{l}0.164 * \\
(2.13) \\
\end{array}$ & $\begin{array}{l}0.170 * \\
(2.07) \\
\end{array}$ & $\begin{array}{l}0.379 \\
(1.39) \\
\end{array}$ & $\begin{array}{l}0.120 \\
(0.34) \\
\end{array}$ & $\begin{array}{l}-0.135 \\
(-1.55) \\
\end{array}$ & $\begin{array}{l}-0.136 \\
(-1.57) \\
\end{array}$ \\
\hline $\mathbf{R}^{2}$ & 48.45 & 44.45 & 58.92 & 66.47 & 46.99 & 47.79 & 55.84 & 60.66 & 27.51 & 29.81 \\
\hline Adjusted $\mathbf{R}^{2}$ & & 9.72 & & 45.51 & & 18.77 & & 38.80 & & -0.09 \\
\hline F-statistic & & 1.28 & & 3.17 & & 1.65 & & 2.77 & & 0.76 \\
\hline Durbin Watson & & 2.63 & & 2.58 & & 2.47 & & 1.35 & & 1.43 \\
\hline J statistic & 4.34 & & 3.29 & & 1.58 & & 2.98 & & 2.65 & \\
\hline Prob.(J-stat) & 0.11 & & 0.19 & & 0.45 & & 0.22 & & 0.26 & \\
\hline Instrument & 8 & & 8 & & 8 & & 8 & & 8 & \\
\hline $\begin{array}{l}\text { GMM = Arellano } \\
\text { heteroscedasticity. } \\
=\text { bank net interest } \\
\text { ratio of bank non- }\end{array}$ & $\begin{array}{l}\text { nd Generali } \\
\text { riable descri } \\
\text { rgin; } L D=b \\
\text { rming loans }\end{array}$ & $\begin{array}{l}\text { method } \\
\text { n: ROA = } \\
\text { lending-c } \\
\text { gross loan }\end{array}$ & $\begin{array}{l}\text { er-tax returr } \\
\text { sit spread; } \\
\mathrm{NF} \text { inflati }\end{array}$ & $\begin{array}{l}-\mathrm{HAC}= \\
\text { assets; } \mathrm{RC} \\
\mathrm{F}=\text { bank cc } \\
* * *, * *, *\end{array}$ & $\begin{array}{l}=\text { after-tax } 1 \\
\text { income ra } \\
\text { ote signific }\end{array}$ & $\begin{array}{l}\text { are regres } \\
\mathrm{n} \text { on equit } \\
\mathrm{CAR}=\text { rat } \\
\text { at the } 1 \%\end{array}$ & $\begin{array}{l}\text { with New } \\
\mathrm{I}=\text { bank } \mathrm{n} \\
\text { bank regu } \\
\text { and } 10 \% \mathrm{I}\end{array}$ & $\begin{array}{l}\text { vest correc } \\
\text { terest incor } \\
\text { y capital to } \\
\text { s. }\end{array}$ & $\begin{array}{l}\text { for auto } \\
\text { total inc } \\
\text { K-weighte }\end{array}$ & $\begin{array}{l}\text { lation and } \\
\text { ratio; NIM } \\
\text { ets; NPL = }\end{array}$ \\
\hline
\end{tabular}




\subsubsection{Effect of financial development on bank profitability}

The result is reported in table 4. For the financial development variables, the CD coefficient is positive and significantly related to profitability (NII) in columns 7 and 8 as expected. This indicates that domestic credit to private sector $(\mathrm{CD})$ has a significant and positive effect on the non-interest income of banks in Nigeria. This implies that higher financial development, measured by domestic credit to private sector as a percentage of GDP, improves the non-interest income of Nigerian banks. This result supports the findings of Beck et al (2010) and Ayadi et al (2015). On the other hand, the $\mathrm{CD}$ coefficient is negative and significantly related to the lending to deposit spread (LD) in columns 9 and 10. This indicates that domestic credit to private sector has a significant negative effect on the lending-to-deposit spread in Nigeria, which is inconsistent with our prediction.

The FD coefficient is positive and significantly related with LD in columns $9 \& 10$. This indicates that a large financial system (FD) has a significant positive effect on the lending-to-deposit spread in Nigeria, which is consistent with the findings of prior studies (Beck et al, 2010; Zhang et al, 2012; Ozili, 2019). Also, the FD coefficient is negative and significantly related to NII in columns $7 \& 8$, and suggests that a large financial system has a significant negative effect on the noninterest income of banks in Nigeria, which is inconsistent with our prediction.

The $\mathrm{CN}$ coefficient is positive and significantly related to NII and LD in column 7, 8, 9 and 10 as expected. This suggests that higher banking concentration has a significant positive effect on bank profitability in Nigeria. The positive and significant relationship between CN and NII and LD is consistent with the expectation that banks in concentrated banking sector can use their oligopolistic advantage in the market to charge higher fees in order to increase bank profit. (Dietrich and Wanzenried, 2011; Beck et al, 2006). 


\begin{tabular}{|c|c|c|c|c|c|c|c|c|c|c|}
\hline \multicolumn{11}{|c|}{ Table 4: Impact of financial development on bank profitability } \\
\hline & \multicolumn{2}{|c|}{ Dependent variable: ROA } & \multicolumn{2}{|c|}{ Dependent variable: ROE } & \multicolumn{2}{|c|}{ Dependent variable: NIM } & \multicolumn{2}{|c|}{ Dependent variable: NII } & \multicolumn{2}{|c|}{ Dependent variable: LD } \\
\hline & (1) & (2) & (3) & (4) & (5) & $(6)$ & (7) & $(8)$ & (9) & $(10)$ \\
\hline & GMM & OLS-HAC & GMM & OLS-HAC & GMM & OLS-HAC & GMM & OLS-HAC & GMM & OLS-HAC \\
\hline & $\begin{array}{l}\text { Coefficient } \\
\text { (t-statistic) }\end{array}$ & $\begin{array}{l}\text { Coefficient } \\
\text { (t-statistic) }\end{array}$ & $\begin{array}{r}\text { Coefficient } \\
\text { (t-statistic) }\end{array}$ & $\begin{array}{c}\text { Coefficient } \\
\text { (t-statistic) }\end{array}$ & $\begin{array}{l}\text { Coefficient } \\
\text { (t-statistic) }\end{array}$ & $\begin{array}{c}\text { Coefficient } \\
\text { (t-statistic) }\end{array}$ & $\begin{array}{c}\text { Coefficient } \\
\text { (t-statistic) }\end{array}$ & $\begin{array}{r}\text { Coefficient } \\
\text { (t-statistic) }\end{array}$ & $\begin{array}{c}\text { Coefficient } \\
\text { (t-statistic) }\end{array}$ & $\begin{array}{c}\text { Coefficient } \\
\text { (t-statistic) }\end{array}$ \\
\hline $\mathbf{C}$ & $\begin{array}{c}27.142 * \\
(3.87)\end{array}$ & $\begin{array}{c}11.449 * \\
(2.32)\end{array}$ & $\begin{array}{c}379.312 * * \\
(4.80)\end{array}$ & $\begin{array}{c}104.4 * * \\
(3.19)\end{array}$ & $\begin{array}{l}10.591 \\
(1.85)\end{array}$ & $\begin{array}{l}14.172 \\
(1.49)\end{array}$ & $\begin{array}{c}69.274 * * * \\
(20.11)\end{array}$ & $\begin{array}{c}68.119 * * * * \\
(11.68)\end{array}$ & $\begin{array}{c}14.503 * * * * \\
(4.93)\end{array}$ & $\begin{array}{c}12.679 * * \\
(2.84)\end{array}$ \\
\hline CAR & $\begin{array}{l}-0.118 \\
(-1.45)\end{array}$ & $\begin{array}{l}-0.066 \\
(-1.79)\end{array}$ & $\begin{array}{l}-2.785 \\
(-2.49)\end{array}$ & $\begin{array}{l}-0.144 \\
(-0.40)\end{array}$ & $\begin{array}{l}0.060 \\
(0.26)\end{array}$ & $\begin{array}{l}-0.012 \\
(-0.05)\end{array}$ & $\begin{array}{c}-0.359 * * * \\
(-3.92)\end{array}$ & $\begin{array}{c}-0.330^{* *} \\
(-2.78)\end{array}$ & $\begin{array}{l}0.039 \\
(0.53)\end{array}$ & $\begin{array}{l}0.026 \\
(0.32)\end{array}$ \\
\hline EFF & $\begin{array}{l}-0.156 \\
(-6.17)\end{array}$ & $\begin{array}{l}-0.175 \\
(-1.68)\end{array}$ & $\begin{array}{c}-1.961 * * * \\
(-12.38)\end{array}$ & $\begin{array}{l}-1.638^{*} \\
(-2.55)\end{array}$ & $\begin{array}{l}-0.025 \\
(-0.28)\end{array}$ & $\begin{array}{l}-0.036 \\
(-0.36)\end{array}$ & $\begin{array}{l}-0.159^{*} \\
(-2.12)\end{array}$ & $\begin{array}{l}-0.159 \\
(-0.75)\end{array}$ & $\begin{array}{c}-0.304 * * \\
(-2.61)\end{array}$ & $\begin{array}{l}-0.229 \\
(-1.35)\end{array}$ \\
\hline NPL & $\begin{array}{l}-0.353^{*} \\
(-3.29)\end{array}$ & $\begin{array}{l}0.007 \\
(0.16)\end{array}$ & $\begin{array}{l}-4.664 * \\
(-3.85)\end{array}$ & $\begin{array}{l}0.091 \\
(0.21)\end{array}$ & $\begin{array}{l}0.022 \\
(0.13)\end{array}$ & $\begin{array}{l}-0.031 \\
(-0.18)\end{array}$ & $\begin{array}{l}-0.124 \\
(-1.44)\end{array}$ & $\begin{array}{l}-0.107 \\
(-0.64)\end{array}$ & $\begin{array}{c}0.364 * * \\
(3.62)\end{array}$ & $\begin{array}{l}0.312 * \\
(2.34)\end{array}$ \\
\hline $\mathbf{C N}$ & $\begin{array}{l}-0.009 \\
(-0.51)\end{array}$ & $\begin{array}{l}0.071 \\
(1.61)\end{array}$ & $\begin{array}{l}-0.487 \\
(-1.98)\end{array}$ & $\begin{array}{l}0.448 \\
(1.51)\end{array}$ & $\begin{array}{l}-0.064 \\
(-1.14)\end{array}$ & $\begin{array}{l}-0.100 \\
(-1.18)\end{array}$ & $\begin{array}{c}0.149 * * \\
(3.13)\end{array}$ & $\begin{array}{l}0.155^{*} \\
(2.22)\end{array}$ & $\begin{array}{c}0.175^{* * *} \\
(3.66)\end{array}$ & $\begin{array}{l}0.149 * \\
(2.42)\end{array}$ \\
\hline$\Delta$ GDP & $\begin{array}{l}-0.032 \\
(-2.42)\end{array}$ & $\begin{array}{l}0.026 \\
(0.46)\end{array}$ & $\begin{array}{c}-0.447^{*} \\
(-3.28)\end{array}$ & $\begin{array}{l}0.169 \\
(0.24)\end{array}$ & $\begin{array}{l}0.131 \\
(1.04)\end{array}$ & $\begin{array}{l}0.198 \\
(1.37)\end{array}$ & $\begin{array}{c}-0.437 * * \\
(-3.36)\end{array}$ & $\begin{array}{c}-0.444 * * \\
(-3.09)\end{array}$ & $\begin{array}{l}-0.179 \\
(-1.86)\end{array}$ & $\begin{array}{l}-0.159 \\
(-1.52)\end{array}$ \\
\hline CD & $\begin{array}{l}0.008 \\
(0.27)\end{array}$ & $\begin{array}{l}-0.070 \\
(-0.91)\end{array}$ & $\begin{array}{l}0.579 \\
(1.40)\end{array}$ & $\begin{array}{l}-0.805 \\
(-1.46)\end{array}$ & $\begin{array}{l}-0.004 \\
(-0.03)\end{array}$ & $\begin{array}{l}0.054 \\
(0.36)\end{array}$ & $\begin{array}{c}0.423 * * * \\
(4.19)\end{array}$ & $\begin{array}{c}0.394 * * \\
(2.64)\end{array}$ & $\begin{array}{c}-0.482 * * * \\
(-5.50)\end{array}$ & $\begin{array}{c}-0.449 * * \\
(-4.19)\end{array}$ \\
\hline FD & $\begin{array}{l}-0.694 * \\
(-3.50)\end{array}$ & $\begin{array}{l}-0.041 \\
(-0.58)\end{array}$ & $\begin{array}{c}-9.481 * * \\
(-4.49)\end{array}$ & $\begin{array}{l}-0.461 \\
(-0.76)\end{array}$ & $\begin{array}{l}-0.063 \\
(-0.20)\end{array}$ & $\begin{array}{l}-0.078 \\
(-0.28)\end{array}$ & $\begin{array}{c}-1.817 * * * \\
(-10.28)\end{array}$ & $\begin{array}{c}-1.765 * * * \\
(-5.33)\end{array}$ & $\begin{array}{c}0.577 * * \\
(3.54)\end{array}$ & $\begin{array}{l}0.509 * \\
(2.27)\end{array}$ \\
\hline INF & $\begin{array}{c}0.117 * * \\
(4.72)\end{array}$ & $\begin{array}{c}0.151^{* *} \\
(3.41)\end{array}$ & $\begin{array}{l}0.859 \\
(1.81) \\
\end{array}$ & $\begin{array}{c}1.686^{* *} \\
(3.57)\end{array}$ & $\begin{array}{l}0.079 \\
(0.73)\end{array}$ & $\begin{array}{l}0.011 \\
(0.06)\end{array}$ & $\begin{array}{l}0.181 \\
(1.06)\end{array}$ & $\begin{array}{l}0.198 \\
(0.91)\end{array}$ & $\begin{array}{l}0.102 \\
(0.78)\end{array}$ & $\begin{array}{c}0.044 * * * \\
(0.26)\end{array}$ \\
\hline $\mathbf{R}^{2}$ & 91.88 & 68.82 & 92.57 & 76.61 & 62.76 & 66.25 & 95.42 & 95.52 & 77.10 & 78.82 \\
\hline Adjusted R ${ }^{2}$ & 59.42 & 18.95 & 62.83 & 39.19 & 13.11 & 21.26 & 89.33 & 89.55 & 46.57 & 50.60 \\
\hline F-statistic & & 1.38 & & 2.05 & & 1.47 & & 15.99 & & 2.79 \\
\hline Durbin Watson & & 2.90 & & 2.54 & & 2.61 & & 2.37 & & 2.96 \\
\hline J-statistic & 2.82 & & 2.76 & & 1.95 & & 2.33 & & 1.65 & \\
\hline Prob. (J-stat) & 0.24 & & 0.25 & & 0.37 & & 0.44 & & 0.43 & \\
\hline Instrument & 11 & & 11 & & 11 & & 11 & & 11 & \\
\hline $\begin{array}{l}\text { GMM = Arellan } \\
\text { heteroscedasticity } \\
\text { bank net interest } \\
\text { of bank non-perfo } \\
\text { to GDP; INF = inf }\end{array}$ & $\begin{array}{l}\text { ond Genera } \\
\text { iriable descr } \\
\text { gin; } \mathrm{LD}=\text { ba } \\
\text { ng loans to g } \\
\text { on. ***, **, }\end{array}$ & $\begin{array}{l}\text { ized method } \\
\text { tion: ROA = } \\
\text { k lending-de } \\
\text { oss loans; CI } \\
\text { denote signi }\end{array}$ & $\begin{array}{l}\text { fter-tax returr } \\
\text { sit spread; EF } \\
=\text { bank concer } \\
\text { ance at the } 1\end{array}$ & $\begin{array}{l}\text { S-HAC = } \\
\text { assets; RO } \\
=\text { Bank cost } t \\
\text { tion; } \mathrm{CD}=\mathrm{r} \\
\% \text { and } 10 \%\end{array}$ & $\begin{array}{l}\text { dinary least } \\
=\text { after-tax ret } \\
\text { income ratio; } \\
\text { o of domestic } \\
\text { vels. }\end{array}$ & $\begin{array}{l}\text { uare regres } \\
\text { n on equity } \\
\mathrm{AR}=\text { ratio } \\
\text { edit to priv }\end{array}$ & $\begin{array}{l}\text { on with Nev } \\
\text { II = bank no } \\
\text { oank regulato } \\
\text { sector }(\% \text { of }\end{array}$ & $\begin{array}{l}\text { west correc } \\
\text { erest incom } \\
\text { apital to risk } \\
\text { P); FD = rat }\end{array}$ & $\begin{array}{l}\text { for autocc } \\
\text { total income } \\
\text { eighted asset } \\
\text { f financial sy }\end{array}$ & $\begin{array}{l}\text { relation and } \\
\text { atio; NIM = } \\
\text { NPL = ratio } \\
\text { tem deposits }\end{array}$ \\
\hline
\end{tabular}

\subsubsection{During financial crisis and the post-financial crisis effect}

In this section, we perform some additional analyses to test the impact of financial development on bank profitability in Nigeria during and after the 2007-2008 global financial crisis. To do this, we introduced a 'CRISIS' binary variable to capture the global financial crisis period. The 'CRISIS' binary variable equal ' 1 ' for year 2007 and 2008, and zero otherwise. The CRISIS binary variable is then interacted with the two indicators of financial development: CD and FD. Also, we introduced a post-financial crisis binary variable 'PC' that equal ' 1 ' for year 2009, 2010, 2011, 2012, 2013, 2014, 2015 and 2016, and zero otherwise. The PC binary variable is then interacted 
with the two indicators of financial development: CD and FD. The results are reported in tables 5 and 6. As can be seen in table 5, the CRISIS*CD coefficient is not significantly related to profitability in all the GMM estimations. In the OLS estimations, the CRISIS*CD coefficient is significantly related to profitability (ROE) in column 4, which suggests that higher domestic credit to private sector is associated with higher profits to shareholders in the post-crisis era. However, the conflicting coefficient sign in the GMM and OLS estimation results suggest that the result is inconclusive.

\begin{tabular}{|c|c|c|c|c|c|c|c|c|c|c|}
\hline \multicolumn{11}{|c|}{ Table 5: Effect of financial development on bank profitability during the global financial crisis } \\
\hline & \multicolumn{2}{|c|}{ Dependent variable: ROA } & \multicolumn{2}{|c|}{ Dependent variable: ROE } & \multicolumn{2}{|c|}{ Dependent variable: NIM } & \multicolumn{2}{|c|}{ Dependent variable: NII } & \multicolumn{2}{|c|}{ Dependent variable: LD } \\
\hline & (1) & (2) & (3) & (4) & (5) & (6) & (7) & $(8)$ & (9) & $(10)$ \\
\hline & GMM & OLS-HAC & GMM & OLS-HAC & GMM & OLS-HAC & GMM & OLS-HAC & GMM & OLS-HAC \\
\hline & $\begin{array}{l}\text { Coefficient } \\
\text { (t-statistic) }\end{array}$ & $\begin{array}{l}\text { Coefficient } \\
\text { (t-statistic) }\end{array}$ & $\begin{array}{l}\text { Coefficient } \\
\text { (t-statistic) }\end{array}$ & $\begin{array}{l}\text { Coefficient } \\
\text { (t-statistic) }\end{array}$ & $\begin{array}{l}\text { Coefficient } \\
\text { (t-statistic) }\end{array}$ & $\begin{array}{r}\text { Coefficient } \\
\text { (t-statistic) }\end{array}$ & $\begin{array}{r}\text { Coefficient } \\
\text { (t-statistic) }\end{array}$ & $\begin{array}{l}\text { Coefficient } \\
\text { (t-statistic) }\end{array}$ & $\begin{array}{l}\text { Coefficient } \\
\text { (t-statistic) }\end{array}$ & $\begin{array}{l}\text { Coefficient } \\
\text { (t-statistic) }\end{array}$ \\
\hline $\mathbf{C}$ & $\begin{array}{l}13.391 \\
(2.19)\end{array}$ & $\begin{array}{l}13.39 * \\
(2.85)\end{array}$ & $\begin{array}{c}139.53 * * * \\
(1.65)\end{array}$ & $\begin{array}{c}124.84 * * * \\
(7.35)\end{array}$ & $\begin{array}{c}-10.584 \\
(-0.07)\end{array}$ & $\begin{array}{l}19.40 \\
(1.33)\end{array}$ & $\begin{array}{c}83.547 * * \\
(3.17)\end{array}$ & $\begin{array}{c}67.58^{* * *} \\
(3.85)\end{array}$ & $\begin{array}{c}14.820 * * * \\
(4.10)\end{array}$ & $\begin{array}{l}10.83 \\
(0.78)\end{array}$ \\
\hline CAR & $\begin{array}{l}0.117 \\
(0.81)\end{array}$ & $\begin{array}{l}-0.160 \\
(-2.23)\end{array}$ & $\begin{array}{l}-1.378 \\
(-0.58)\end{array}$ & $\begin{array}{c}-1.075^{* * *} \\
(-3.39)\end{array}$ & $\begin{array}{l}-0.089 \\
(-0.08)\end{array}$ & $\begin{array}{l}0.047 \\
(0.14)\end{array}$ & $\begin{array}{l}-0.239 \\
(-0.61)\end{array}$ & $\begin{array}{l}-0.393 \\
(-1.43)\end{array}$ & $\begin{array}{l}0.086 \\
(0.71)\end{array}$ & $\begin{array}{l}-0.016 \\
(-0.07)\end{array}$ \\
\hline EFF & $\begin{array}{l}-0.159 \\
(-1.45)\end{array}$ & $\begin{array}{l}-0.164 \\
(-1.67)\end{array}$ & $\begin{array}{l}-1.774 \\
(-1.28)\end{array}$ & $\begin{array}{c}-1.539^{* *} \\
(-4.28)\end{array}$ & $\begin{array}{l}0.223 \\
(0.14)\end{array}$ & $\begin{array}{l}-0.114 \\
(-0.85)\end{array}$ & $\begin{array}{l}-0.326 \\
(-0.75)\end{array}$ & $\begin{array}{l}-0.132 \\
(-0.42)\end{array}$ & $\begin{array}{l}-0.258 \\
(-1.98)\end{array}$ & $\begin{array}{l}-0.194 \\
(-0.75)\end{array}$ \\
\hline NPL & $\begin{array}{l}-0.128 \\
(-1.15)\end{array}$ & $\begin{array}{l}-0.093 \\
(-2.29)\end{array}$ & $\begin{array}{l}-1.101^{*} \\
(-2.78)\end{array}$ & $\begin{array}{c}-0.967 * * \\
(-4.45)\end{array}$ & $\begin{array}{l}0.272 \\
(0.14)\end{array}$ & $\begin{array}{l}-0.061 \\
(-0.17)\end{array}$ & $\begin{array}{l}-0.288 \\
(-1.11)\end{array}$ & $\begin{array}{l}-0.148 \\
(-0.61)\end{array}$ & $\begin{array}{l}0.296^{*} \\
(2.64)\end{array}$ & $\begin{array}{l}0.306 \\
(1.56)\end{array}$ \\
\hline $\mathbf{C N}$ & $\begin{array}{l}0.029 \\
(0.69)\end{array}$ & $\begin{array}{l}0.107 \\
(1.67)\end{array}$ & $\begin{array}{l}0.081 \\
(0.12)\end{array}$ & $\begin{array}{l}0.835^{*} \\
(2.81)\end{array}$ & $\begin{array}{l}-0.216 \\
(-0.53)\end{array}$ & $\begin{array}{l}-0.068 \\
(-0.51)\end{array}$ & $\begin{array}{l}0.182 \\
(0.88)\end{array}$ & $\begin{array}{l}0.164 \\
(0.82)\end{array}$ & $\begin{array}{l}0.104 \\
(1.66)\end{array}$ & $\begin{array}{l}0.142 \\
(0.94)\end{array}$ \\
\hline$\Delta$ GDP & $\begin{array}{l}0.016 \\
(0.18)\end{array}$ & $\begin{array}{l}-0.071 \\
(-1.18)\end{array}$ & $\begin{array}{l}0.221 \\
(0.18)\end{array}$ & $\begin{array}{c}-0.856 * * * \\
(-6.72)\end{array}$ & $\begin{array}{l}0.202 \\
(0.48)\end{array}$ & $\begin{array}{l}0.214 \\
(1.84)\end{array}$ & $\begin{array}{l}-0.415 \\
(-1.57)\end{array}$ & $\begin{array}{l}-0.496 \\
(-1.57)\end{array}$ & $\begin{array}{l}-0.122 \\
(-0.72)\end{array}$ & $\begin{array}{l}-0.185 \\
(-0.84)\end{array}$ \\
\hline CD & $\begin{array}{l}-0.073 \\
(-1.59)\end{array}$ & $\begin{array}{l}-0.439 \\
(-1.79)\end{array}$ & $\begin{array}{l}-0.749 \\
(-1.48)\end{array}$ & $\begin{array}{c}-4.676 * * * \\
(-6.31)\end{array}$ & $\begin{array}{l}0.391 \\
(0.27)\end{array}$ & $\begin{array}{l}0.063 \\
(0.07)\end{array}$ & $\begin{array}{l}0.274 \\
(0.49)\end{array}$ & $\begin{array}{l}0.208 \\
(0.17)\end{array}$ & $\begin{array}{c}-0.366^{* *} \\
(-3.17)\end{array}$ & $\begin{array}{l}-0.523 \\
(-0.64)\end{array}$ \\
\hline FD & $\begin{array}{c}0.276 \\
(-1.59)\end{array}$ & $\begin{array}{l}0.632 \\
(1.51)\end{array}$ & $\begin{array}{l}-2.708 \\
(-1.08)\end{array}$ & $\begin{array}{c}6.535 * * * \\
(6.35)\end{array}$ & $\begin{array}{l}0.552 \\
(0.14)\end{array}$ & $\begin{array}{l}-0.435 \\
(-0.30)\end{array}$ & $\begin{array}{c}-2.169 * * \\
(-3.63)\end{array}$ & $\begin{array}{l}-1.329 \\
(-0.67)\end{array}$ & $\begin{array}{l}0.441 \\
(0.27)\end{array}$ & $\begin{array}{l}0.787 \\
(0.59)\end{array}$ \\
\hline INF & $\begin{array}{c}0.171 * * \\
(3.46)\end{array}$ & $\begin{array}{l}0.133 \\
(1.73)\end{array}$ & $\begin{array}{l}1.842 \\
(5.56)\end{array}$ & $\begin{array}{c}1.552^{* *} \\
(5.01)\end{array}$ & $\begin{array}{l}-0.297 \\
(-0.18)\end{array}$ & $\begin{array}{l}0.125 \\
(0.58)\end{array}$ & $\begin{array}{l}0.327 \\
(0.56)\end{array}$ & $\begin{array}{l}0.158 \\
(0.49)\end{array}$ & $\begin{array}{l}-0.008 \\
(-0.04)\end{array}$ & $\begin{array}{l}-0.007 \\
(-0.03)\end{array}$ \\
\hline CRISIS & $\begin{array}{l}-23.056 \\
(-1.07)\end{array}$ & $\begin{array}{c}-13.134 \\
(-1.96)\end{array}$ & $\begin{array}{r}-153.37 \\
(-0.48)\end{array}$ & $\begin{array}{c}-141.16 * * * \\
(-6.77)\end{array}$ & $\begin{array}{l}10.185 \\
(0.29)\end{array}$ & $\begin{array}{l}1.219 \\
(0.04)\end{array}$ & $\begin{array}{l}-2.022 \\
(-0.19)\end{array}$ & $\begin{array}{l}-6.933 \\
(-0.18)\end{array}$ & $\begin{array}{l}-4.523 \\
(-0.10)\end{array}$ & $\begin{array}{l}-3.024 \\
(-0.11)\end{array}$ \\
\hline CRISIS*CD & $\begin{array}{l}1.847 \\
(1.19) \\
\end{array}$ & $\begin{array}{l}0.367 \\
(1.66) \\
\end{array}$ & $\begin{array}{c}13.236 \\
(0.56) \\
\end{array}$ & $\begin{array}{c}4.154 * * \\
(3.37) \\
\end{array}$ & $\begin{array}{l}-0.888 \\
(-0.19) \\
\end{array}$ & $\begin{array}{l}0.117 \\
(0.12) \\
\end{array}$ & $\begin{array}{l}0.426 \\
(0.46) \\
\end{array}$ & $\begin{array}{l}0.154 \\
(0.13) \\
\end{array}$ & $\begin{array}{l}-0.083 \\
(-0.47) \\
\end{array}$ & $\begin{array}{l}0.022 \\
(0.03) \\
\end{array}$ \\
\hline $\mathbf{R}^{2}$ & 70.23 & 84.72 & 39.95 & 96.47 & -61.86 & 71.54 & 95.57 & 95.64 & 86.23 & 79.70 \\
\hline Adjusted $\mathbf{R}^{2}$ & -28.98 & 33.79 & -1.60 & 84.71 & -4.67 & 0.04 & 884.45 & 84.74 & 51.83 & 28.96 \\
\hline F-statistic & & 1.66 & & 8.20 & & 1.01 & & 8.77 & & 1.57 \\
\hline $\begin{array}{l}\text { Durbin } \\
\text { Watson }\end{array}$ & & 3.13 & & 2.88 & & 2.45 & & 2.40 & & 2.98 \\
\hline Prob.(J-stat) & 0.000 & & 0.23 & & 0.000 & & 0.000 & & 0.000 & \\
\hline Instrument & 11 & & 11 & & 11 & & 11 & & 11 & \\
\hline $\begin{array}{l}\text { OLS-HAC = } \\
\text { estimation. Th } \\
\text { assets; ROE = } \\
\text { EFF = Bank cc } \\
\text { Bank concentr } \\
\text { variable that ta }\end{array}$ & $\begin{array}{l}\text { inary least sc } \\
\text { SMM estimat } \\
\text { er-tax return } \\
\text { to income ra } \\
\text { n; } \mathrm{CD}=\text { ratio } \\
\text { the value of } 1\end{array}$ & $\begin{array}{l}\text { are regression } \\
\text { includes the } \\
\text { equity; NII = } \\
\text { o CAR = rati } \\
\text { f domestic cre } \\
\text { or } 2009 \text { to } 20\end{array}$ & $\begin{array}{l}\text { with Newey v } \\
\text { Jewey-West c } \\
\text { Bank noninter } \\
\text { of bank regulc } \\
\text { lit to private se } \\
6 \text {, and zero oth }\end{array}$ & $\begin{array}{l}\text { st correction } \\
\text { rection for at } \\
\text { t income to to } \\
\text { ory capital to } \\
\text { tor (\% of GDI } \\
\text { wise. ***, ** }\end{array}$ & $\begin{array}{l}\text { or autocorrela } \\
\text { ocorrelation a } \\
\text { al income rati } \\
\text { sk-weighted } \\
\text {; FD = ratio o } \\
* \text { denote sign }\end{array}$ & $\begin{array}{l}\text { on and heter } \\
\text { heterosced } \\
\text { NIM = Ban } \\
\text { ets; NPL = } \\
\text { inancial syst } \\
\text { cance at the }\end{array}$ & $\begin{array}{l}\text { scedasticity. } \\
\text { sticity. Varia } \\
\text { net interest } \\
\text { atio of bank } \\
m \text { deposits t } \\
\%, 5 \% \text { and } 1\end{array}$ & $\begin{array}{l}\mathrm{HMM}=\text { Gene } \\
\text { e description } \\
\text { argin; } \mathrm{LD}=\mathrm{B} \\
\text { on-performing } \\
\text { GDP; INF = II } \\
\text { o levels }\end{array}$ & $\begin{array}{l}\text { alized methoc } \\
\text { ROA = after } \\
\text { ink lending-d } \\
\text { loans to gros } \\
\text { lation. CRIS }\end{array}$ & $\begin{array}{l}\text { of moments } \\
\text { ax return on } \\
\text { posit spread; } \\
\text { loans; } \mathrm{CN}= \\
=\text { a dummy }\end{array}$ \\
\hline
\end{tabular}


Next, we analyze the impact of size of the financial system on bank profitability in the postfinancial crisis era. The variable of interest is the PC*FD interaction variable. The result is reported in table 6 . The PC*FD coefficient is not significantly related to profitability in all the GMM and OLS estimations. Therefore, the results indicate that the size of the financial system does not have a significant impact on the profitability of the banking sector in Nigeria particularly in the postfinancial crisis period.

\begin{tabular}{|c|c|c|c|c|c|c|c|c|c|c|}
\hline \multicolumn{11}{|c|}{ Table 6: Effect of financial development on bank profitability in the post-global financial crisis period } \\
\hline & \multicolumn{2}{|c|}{ Dependent variable: ROA } & \multicolumn{2}{|c|}{ Dependent variable: ROE } & \multicolumn{2}{|c|}{ Dependent variable: NIM } & \multicolumn{2}{|c|}{ Dependent variable: NII } & \multicolumn{2}{|c|}{ Dependent Variable: LD } \\
\hline & $(1)$ & (2) & (3) & (4) & (5) & (6) & (7) & $(8)$ & (9) & $(10)$ \\
\hline & GMM & OLS-HAC & GMM & OLS-HAC & GMM & OLS-HAC & GMM & OLS-HAC & GMM & OLS-HAC \\
\hline & $\begin{array}{l}\text { Coefficient } \\
\text { (t-statistic) }\end{array}$ & $\begin{array}{l}\text { Coefficient } \\
\text { (t-statistic) }\end{array}$ & $\begin{array}{l}\text { Coefficient } \\
\text { (t-statistic) }\end{array}$ & $\begin{array}{c}\text { Coefficient } \\
\text { (t-statistic) }\end{array}$ & $\begin{array}{c}\text { Coefficient } \\
\text { (t-statistic) }\end{array}$ & $\begin{array}{c}\text { Coefficient } \\
\text { (t-statistic) }\end{array}$ & $\begin{array}{c}\text { Coefficient } \\
\text { (t-statistic) }\end{array}$ & $\begin{array}{c}\text { Coefficient } \\
\text { (t-statistic) }\end{array}$ & $\begin{array}{c}\text { Coefficient } \\
\text { (t-statistic) }\end{array}$ & $\begin{array}{c}\text { Coefficient } \\
\text { (t-statistic) }\end{array}$ \\
\hline C & $\begin{array}{l}13.390 \\
(2.19)\end{array}$ & $\begin{array}{l}11.03^{*} \\
(3.27)\end{array}$ & $\begin{array}{c}139.53 \\
(1.65)\end{array}$ & $\begin{array}{c}109.70 * * \\
(4.78)\end{array}$ & $\begin{array}{c}-117.45 \\
(-0.05)\end{array}$ & $\begin{array}{l}18.56^{*} \\
(2.59)\end{array}$ & $\begin{array}{c}82.056^{* * *} \\
(3.56)\end{array}$ & $\begin{array}{c}66.52 * * * \\
(11.87)\end{array}$ & $\begin{array}{c}14.809 * * \\
(4.17)\end{array}$ & $\begin{array}{l}10.77 \\
(1.76)\end{array}$ \\
\hline CAR & $\begin{array}{l}0.116 \\
(0.81)\end{array}$ & $\begin{array}{l}-0.121 \\
(-1.43)\end{array}$ & $\begin{array}{l}1.379 \\
(0.59)\end{array}$ & $\begin{array}{l}-1.071 \\
(-1.36)\end{array}$ & $\begin{array}{l}-1.301 \\
(-0.05)\end{array}$ & $\begin{array}{l}0.066 \\
(0.43)\end{array}$ & $\begin{array}{l}-0.184 \\
(-0.39)\end{array}$ & $\begin{array}{l}-0.368 \\
(-1.69)\end{array}$ & $\begin{array}{l}0.073 \\
(0.59)\end{array}$ & $\begin{array}{l}-0.014 \\
(-0.09)\end{array}$ \\
\hline EFF & $\begin{array}{l}-0.159 \\
(-1.45)\end{array}$ & $\begin{array}{l}-0.157 \\
(-1.78)\end{array}$ & $\begin{array}{l}-1.774 \\
(-1.29)\end{array}$ & $\begin{array}{c}-1.438 * * \\
(-4.06)\end{array}$ & $\begin{array}{l}1.229 \\
(0.05)\end{array}$ & $\begin{array}{l}-0.104 \\
(-0.76)\end{array}$ & $\begin{array}{l}-0.297 \\
(-0.75)\end{array}$ & $\begin{array}{l}-0.117 \\
(-0.44)\end{array}$ & $\begin{array}{l}-0.261 \\
(-2.02)\end{array}$ & $\begin{array}{l}-0.188 \\
(-0.83)\end{array}$ \\
\hline NPL & $\begin{array}{l}-0.128 \\
(-1.15)\end{array}$ & $\begin{array}{l}-0.028 \\
(-0.39)\end{array}$ & $\begin{array}{l}-1.101 \\
(-0.65)\end{array}$ & $\begin{array}{l}-0.507 \\
(-0.94)\end{array}$ & $\begin{array}{l}1.973 \\
(0.05)\end{array}$ & $\begin{array}{l}-0.018 \\
(-0.12)\end{array}$ & $\begin{array}{l}-0.310 \\
(-1.32)\end{array}$ & $\begin{array}{l}-0.087 \\
(-0.44)\end{array}$ & $\begin{array}{c}0.305^{*} \\
(2.52)\end{array}$ & $\begin{array}{l}0.323 \\
(2.12)\end{array}$ \\
\hline $\mathbf{C N}$ & $\begin{array}{l}0.029 \\
(0.69)\end{array}$ & $\begin{array}{l}0.099 \\
(1.79)\end{array}$ & $\begin{array}{l}0.081 \\
(0.12)\end{array}$ & $\begin{array}{l}0.717 \\
(2.10)\end{array}$ & $\begin{array}{l}-0.317 \\
(-0.10)\end{array}$ & $\begin{array}{l}-0.116 \\
(-1.15)\end{array}$ & $\begin{array}{l}0.161 \\
(0.94)\end{array}$ & $\begin{array}{l}0.091 \\
(0.53)\end{array}$ & $\begin{array}{l}0.107 \\
(1.83)\end{array}$ & $\begin{array}{l}0.108 \\
(0.88)\end{array}$ \\
\hline$\Delta$ GDP & $\begin{array}{l}0.016 \\
(0.18)\end{array}$ & $\begin{array}{l}-0.042 \\
(-1.61)\end{array}$ & $\begin{array}{l}0.221 \\
(0.18)\end{array}$ & $\begin{array}{l}-0.521 \\
(-1.57)\end{array}$ & $\begin{array}{l}0.112 \\
(0.05)\end{array}$ & $\begin{array}{l}0.294 \\
(1.78)\end{array}$ & $\begin{array}{l}-0.421 \\
(-1.56)\end{array}$ & $\begin{array}{l}-0.376 \\
(-1.31)\end{array}$ & $\begin{array}{l}-0.122 \\
(-0.73)\end{array}$ & $\begin{array}{l}-0.131 \\
(-0.74)\end{array}$ \\
\hline CD & $\begin{array}{l}-0.0 .73 \\
(-1.59)\end{array}$ & $\begin{array}{l}-0.279 \\
(-2.22)\end{array}$ & $\begin{array}{l}-0.749 \\
(-1.47)\end{array}$ & $\begin{array}{l}-3.367 \\
(-2.07)\end{array}$ & $\begin{array}{l}1.333 \\
(0.06)\end{array}$ & $\begin{array}{l}0.295 \\
(1.72)\end{array}$ & $\begin{array}{l}0.296 \\
(0.58)\end{array}$ & $\begin{array}{l}0.549 \\
(1.47)\end{array}$ & $\begin{array}{c}-0.367 * * \\
(-3.27)\end{array}$ & $\begin{array}{l}-0.387 \\
(-1.42)\end{array}$ \\
\hline FD & $\begin{array}{l}-0.277 \\
(-1.59)\end{array}$ & $\begin{array}{l}0.353 \\
(1.59)\end{array}$ & $\begin{array}{l}-0.749 \\
(-1.48)\end{array}$ & $\begin{array}{l}4.648 \\
(1.44)\end{array}$ & $\begin{array}{l}4.037 \\
(0.05)\end{array}$ & $\begin{array}{l}-0.735 \\
(-1.41)\end{array}$ & $\begin{array}{c}-2.196^{* * *} \\
(-3.91)\end{array}$ & $\begin{array}{c}-1.762 * \\
(-2.69)\end{array}$ & $\begin{array}{c}0.456^{*} \\
(2.54)\end{array}$ & $\begin{array}{l}0.633 \\
(1.18)\end{array}$ \\
\hline INF & $\begin{array}{c}0.171^{* *} \\
(3.46)\end{array}$ & $\begin{array}{l}0.157 \\
(1.48)\end{array}$ & $\begin{array}{l}1.842 \\
(1.94)\end{array}$ & $\begin{array}{c}1.453^{* *} \\
(3.24)\end{array}$ & $\begin{array}{l}-1.322 \\
(-0.05)\end{array}$ & $\begin{array}{l}0.058 \\
(0.34)\end{array}$ & $\begin{array}{l}0.313 \\
(0.56)\end{array}$ & $\begin{array}{l}0.054 \\
(0.11)\end{array}$ & $\begin{array}{l}-0.008 \\
(-0.04)\end{array}$ & $\begin{array}{l}-0.064 \\
(-0.19)\end{array}$ \\
\hline PC & $\begin{array}{c}-149.98 \\
(-1.17)\end{array}$ & $\begin{array}{l}-25.70^{*} \\
(-2.48)\end{array}$ & $\begin{array}{c}-106.26 \\
(-0.53)\end{array}$ & $\begin{array}{c}-179.68^{*} \\
(-3.11)\end{array}$ & $\begin{array}{l}873.28 \\
(0.06)\end{array}$ & $\begin{array}{c}35.075 \\
(1.82)\end{array}$ & $\begin{array}{c}-79.471 \\
(-0.45)\end{array}$ & $\begin{array}{c}45.865 \\
(0.82)\end{array}$ & $\begin{array}{l}21.367 \\
(-0.56)\end{array}$ & $\begin{array}{c}-25.119 \\
(-0.63)\end{array}$ \\
\hline PC*FD & $\begin{array}{l}8.869 \\
(1.19)\end{array}$ & $\begin{array}{l}1.199 \\
(1.94)\end{array}$ & $\begin{array}{c}63.534 \\
(0.55)\end{array}$ & $\begin{array}{l}6.761 \\
(1.56)\end{array}$ & $\begin{array}{c}-52.653 \\
(-0.05)\end{array}$ & $\begin{array}{l}-1.613 \\
(-1.56)\end{array}$ & $\begin{array}{l}4.876 \\
(0.47)\end{array}$ & $\begin{array}{l}-2.564 \\
(-0.85)\end{array}$ & $\begin{array}{l}-1.056 \\
(-0.48)\end{array}$ & $\begin{array}{l}-1.468 \\
(-0.70)\end{array}$ \\
\hline $\mathbf{R}^{2}$ & 70.23 & 87.82 & 39.95 & 93.47 & -18.96 & 75.06 & 95.79 & 96.45 & 86.56 & 82.04 \\
\hline Adj. $\mathbf{R}^{2}$ & -28.98 & 47.22 & -1.60 & 71.71 & -68.87 & 12.71 & 85.28 & 87.56 & 52.98 & 37.15 \\
\hline F-statistic & & 2.16 & & 4.29 & & 1.20 & & 10.85 & & 1.83 \\
\hline $\begin{array}{l}\text { Durbin } \\
\text { Watson }\end{array}$ & & 3.39 & & 2.84 & & 2.96 & & 2.40 & & 3.14 \\
\hline Prob(J-stat) & 0.000 & & 0.000 & & 0.000 & & 0.000 & & 0.000 & \\
\hline Instrument & 11 & & 11 & & 11 & & 11 & & 11 & \\
\hline $\begin{array}{l}\text { OLS-HAC = O } \\
\text { The GMM esti } \\
\text { tax return on ec } \\
\text { ratio; CAR = r } \\
\text { domestic credi } \\
\text { levels }\end{array}$ & $\begin{array}{l}\text { nary least squa } \\
\text { tor includes th } \\
\text { y; NII = Bank } \\
\text { of bank regul } \\
\text { private sector }\end{array}$ & $\begin{array}{l}\text { regression wi } \\
\text { Newey-West c } \\
\text { oninterest inco } \\
\text { ory capital to } \\
\% \text { of GDP); F }\end{array}$ & $\begin{array}{l}\text { h Newey wes } \\
\text { orrection for a } \\
\text { ne to total inc } \\
\text { isk-weighted } \\
=\text { ratio of } f\end{array}$ & $\begin{array}{l}\text { orrection for } \\
\text { ocorrelation } \\
\text { ne ratio; NIN } \\
\text { sets; NPL = } \\
\text { incial systen }\end{array}$ & $\begin{array}{l}\text { ocorrelation } \\
\text { heterosced } \\
\text { Bank net in } \\
\text { o of bank n } \\
\text { eposits to G }\end{array}$ & $\begin{array}{l}\mathrm{d} \text { heteroscec } \\
\text { city. Variab } \\
\text { est margin; I } \\
\text { performing } \\
\text { INF = Infl }\end{array}$ & $\begin{array}{l}\text { sticity. GMI } \\
\text { description } \\
=\text { Bank len } \\
\text { ans to gross } \\
\text { on. ***, ** }\end{array}$ & $\begin{array}{l}\text { eneralized } \\
=\text { after-ta } \\
\text { leposit spr } \\
\text {; } \mathrm{CN}=\mathrm{Ba} \\
\text { note signi }\end{array}$ & $\begin{array}{l}\text { hod of mom } \\
\text { urn on asse } \\
\text { EFF = Ban } \\
\text { oncentratio } \\
\text { ce at the } 1\end{array}$ & $\begin{array}{l}\text { ts estimation. } \\
\text { ROE = after- } \\
\text { ost to income } \\
\mathrm{CD}=\text { ratio of } \\
5 \% \text { and } 10 \%\end{array}$ \\
\hline
\end{tabular}




\subsubsection{Robustness checks}

Although the GMM estimations already control for endogeneity problems, we perform an additional robustness test to control for any other endogeneity problems. Endogeneity problems may arise from reverse causality and omitted variables. To address this issue, we estimated a twostage least squares regression (2SLS) with instrumental variables. The instruments used in the twostage least square regression estimation are: CAR, EFF, NPL, $\triangle \mathrm{GDP}, \mathrm{INF}, \mathrm{CN}$, one-year lagged $\mathrm{CD}$, two-year lagged CD, one-year lagged FD and two-year lagged FD. The results are reported in table 7. The results show that CD coefficient is not significantly related to NII or LD. This suggests that the earlier result is not robust to alternative estimations. Meanwhile, the FD coefficient is negatively related to NII in column 4, which confirms our earlier result in table 4, and suggest that the result is robust after controlling for endogeneity. The result indicates that greater financial development is associated with fewer non-interest income for Nigerian banks.

\begin{tabular}{|c|c|c|c|c|c|}
\hline \multicolumn{6}{|c|}{ Table 7: Further robustness test: Two-stage least square estimation with instrumental variables } \\
\hline & (1) & (2) & (3) & (4) & (5) \\
\hline & Dependent & Dependent & Dependent & Dependent & Dependent \\
\hline & Variable: ROA & Variable: ROE & Variable: NIM & Variable: NII & Variable: LD \\
\hline & $\begin{array}{l}\text { Coefficient } \\
\text { (t-statistic) }\end{array}$ & $\begin{array}{l}\text { Coefficient } \\
\text { (t-statistic) }\end{array}$ & $\begin{array}{l}\text { Coefficient } \\
\text { (t-statistic) }\end{array}$ & $\begin{array}{l}\text { Coefficient } \\
\text { (t-statistic) }\end{array}$ & $\begin{array}{l}\text { Coefficient } \\
\text { (t-statistic) }\end{array}$ \\
\hline \multirow[t]{2}{*}{$\mathbf{C}$} & $12.050 * *$ & $110.05 * *$ & 12.842 & $68.272 * * *$ & 13.846 \\
\hline & $(2.73)$ & (3.04) & $(1.54)$ & $(7.30)$ & (1.89) \\
\hline \multirow[t]{2}{*}{ CAR } & -0.073 & -0.195 & 0.069 & -0.339 & -0.041 \\
\hline & $(-0.96)$ & $(-0.31)$ & $(0.35)$ & $(-1.51)$ & $(-0.23)$ \\
\hline \multirow[t]{2}{*}{ EFF } & $-0.175^{*}$ & $-1.664 * *$ & -0.109 & -0.152 & -0.173 \\
\hline & $(-2.45)$ & $(-2.84)$ & $(-0.66)$ & $(-0.81)$ & $(-1.19)$ \\
\hline \multirow[t]{2}{*}{ NPL } & -0.004 & -0.009 & 0.081 & -0.119 & 0.224 \\
\hline & $(-0.06)$ & $(-0.02)$ & $(0.41)$ & $(-0.53)$ & (1.28) \\
\hline \multirow[t]{2}{*}{$\mathrm{CN}$} & 0.074 & 0.489 & -0.017 & 0.146 & 0.097 \\
\hline & (1.62) & (1.31) & $(-0.15)$ & (1.10) & $(0.94)$ \\
\hline \multirow[t]{2}{*}{$\Delta$ GDP } & 0.027 & 0.172 & 0.168 & $-0.441^{*}$ & -0.138 \\
\hline & $(0.38)$ & $(0.29)$ & $(0.96)$ & $(-2.26)$ & $(-0.91)$ \\
\hline \multirow[t]{2}{*}{$\mathrm{CD}$} & -0.074 & -0.873 & -0.102 & 0.409 & -0.344 \\
\hline & $(-0.87)$ & $(-1.24)$ & $(-0.47)$ & (1.71) & $(-1.84)$ \\
\hline \multirow[t]{2}{*}{ FD } & -0.069 & -0.696 & 0.038 & $-1.779 * * *$ & 0.392 \\
\hline & $(-0.50)$ & $(-0.62)$ & $(0.12)$ & $(-4.88)$ & (1.38) \\
\hline \multirow[t]{2}{*}{ INF } & 0.155 & $1.745^{*}$ & 0.114 & 0.188 & -0.025 \\
\hline & (1.65) & $(2.26)$ & $(0.51)$ & $(0.75)$ & $(-0.13)$ \\
\hline $\mathbf{R}^{2}$ & 68.47 & 76.26 & 59.69 & 95.55 & 76.77 \\
\hline Adjusted $\mathbf{R}^{2}$ & 18.04 & 38.29 & 59.64 & 89.54 & 45.81 \\
\hline F-statistic & 1.38 & 2.07 & 1.24 & 15.85 & 1.76 \\
\hline Durbin Watson & 2.89 & 2.48 & 2.92 & 2.33 & 2.38 \\
\hline J-statistic & 2.20 & 1.16 & 1.53 & 4.09 & 4.19 \\
\hline Prob. (J-stat) & 0.37 & 0.22 & 0.46 & 0.13 & 0.12 \\
\hline Instrument rank & 11 & 11 & 11 & 11 & 11 \\
\hline
\end{tabular}




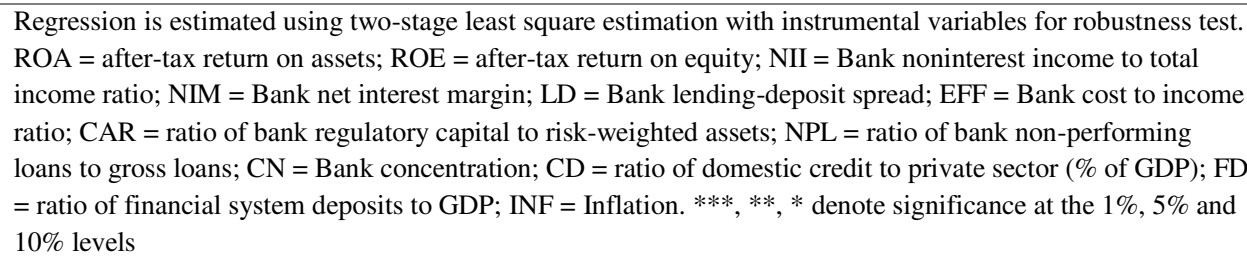

\section{Conclusion}

The paper investigated the impact of financial development on bank profitability in Nigeria after controlling for bank-specific and macroeconomic factors. The study used several profitability and financial development indicators. The findings revealed that the size of the financial system is inversely related to the non-interest income of banks in Nigeria. In other words, higher financial system deposits to GDP depresses the non-interest income of Nigerian banks. Additionally, we find that bank concentration, nonperforming loans, cost efficiency and the level of inflation are significant determinants of bank profitability in Nigeria. Overall, the results show that the size of the financial system, a proxy for financial development, is a significant determinant of bank profitability, and more precisely, non-interest income. Our study does not explore the mechanisms through which this happens.

One implication of the findings for regulators is that regulators may need to formulate marketenabling policies that encourage new banks to emerge in the banking industry. The entry of new banks can increase financial system deposits and credit supply for economic growth. Regulators also need to understand the role of Nigerian banks in promoting financial development, and find ways to collaborate with banks towards greater financial sector development. Another implication of the findings for asset managers is that asset managers will need to take into account the prevailing level of financial development, particularly the size of the financial system, in their asset pricing and investment decisions. This will ensure that investors get value for their investments in Nigeria. The financial implication of the study is that the level of financial development in Nigeria can improve the finance-growth linkages in Nigeria through the efficient allocation of credit and capital to crucial sectors of the Nigerian economy to spur growth in those sectors. 
Future studies should explore the relationship between bank profitability and financial development using other measures of financial development. Future research can also examine other channels through which financial development affects bank profitability. Future studies can explore how the econometric methodology used in this study can be adapted to other developed economies where the levels of financial development are already high. Future studies can also explore whether the dynamics between financial development and bank profitability differ for Islamic banks and conventional banks in Nigeria. Finally, the effect of financial development is likely to occur beyond the banking industry; therefore, future studies can investigate the effect of financial development on the profitability of non-bank financial institutions. 


\section{Reference}

Adeniyi, O., Oyinlola, A., Omisakin, O., \& Egwaikhide, F. O. (2015). Financial development and economic growth in Nigeria: Evidence from threshold modelling. Economic Analysis and Policy, 47, 11-21.

Adu, G., Marbuah, G., \& Mensah, J. T. (2013). Financial development and economic growth in Ghana: does the measure of financial development matter? Review of Development finance, 3(4), 192-203.

Ahamed, M. M. (2017). Asset quality, non-interest income, and bank profitability: Evidence from Indian banks. Economic Modelling, 63, 1-14.

Akimov, A., Wijeweera, A., \& Dollery, B. (2009). Financial development and economic growth: evidence from transition economies. Applied Financial Economics, 19(12), 999-1008.

Anarfo, E. B., \& Appiahene, E. (2017). The impact of capital structure on banks' profitability in Africa. Journal of accounting and Finance, 17(2), 55-66.

Arellano, M., \& Bond, S. (1991). Some tests of specification for panel data: Monte Carlo evidence and an application to employment equations. The review of economic studies, 58(2), 277-297.

Ayadi, R., Arbak, E., Naceur, S. B., \& De Groen, W. P. (2015). Determinants of financial development across the Mediterranean. In Economic and Social Development of the Southern and Eastern Mediterranean Countries (pp. 159-181). Springer, Cham.

Banyen, K., \& Biekpe, N. (2020). Financial integration and bank profitability in five regional economic communities in Africa. International Journal of Emerging Markets, 16(3), 468-491.

Beck, T., Demirgüç-Kunt, A., \& Levine, R. (2006). Bank concentration, competition, and crises: First results. Journal of Banking \& Finance, 30(5), 1581-1603.

Beck, T., Demirgüç-Kunt, A., \& Levine, R. (2010). Financial institutions and markets across countries and over time: The updated financial development and structure database. The World Bank Economic Review, 24(1), 77-92.

Bikker, J. A., \& Vervliet, T. M. (2018). Bank profitability and risk-taking under low interest rates. International Journal of Finance \& Economics, 23(1), 3-18.

Bolarinwa, S. T., Obembe, O. B., \& Olaniyi, C. (2019). Re-examining the determinants of bank profitability in Nigeria. Journal of Economic Studies, 46(3), 633-651. 
Bolt, W., De Haan, L., Hoeberichts, M., Van Oordt, M. R., \& Swank, J. (2012). Bank profitability during recessions. Journal of Banking \& Finance, 36(9), 2552-2564.

Borio, C., Gambacorta, L., \& Hofmann, B. (2017). The influence of monetary policy on bank profitability. International Finance, 20(1), 48-63.

Dabla-Norris, E., Kersting, E. K., \& Verdier, G. (2012). Firm productivity, innovation, and financial development. Southern Economic Journal, 79(2), 422-449.

De Gregorio, J., \& Guidotti, P. E. (1995). Financial development and economic growth. World development, 23(3), 433-448.

Demirguç-Kunt A and H. Huizinga. (2001). Financial Structure and Bank Profitability. In Financial Structure and Economic Growth: A CrossCountry Comparison of Banks. Markets. and Development. Eds. Asli Demirguc-Kunt and Ross Levine. Cambridge. MA: MIT Press.

Dietrich, A., \& Wanzenried, G. (2011). Determinants of bank profitability before and during the crisis: Evidence from Switzerland. Journal of International Financial Markets, Institutions and Money, 21(3), 307-327.

Dwumfour, R. A., \& Ntow-Gyamfi, M. (2018). Natural resources, financial development and institutional quality in Africa: is there a resource curse? Resources Policy, 59, 411-426.

Ebenezer, O. O., Omar, W. A. W. B., \& Kamil, S. (2017). Bank specific and macroeconomic determinants of commercial bank profitability: Empirical evidence from Nigeria. International Journal of Finance \& Banking Studies, 6(1), 25.

Effiong, E. (2015). Financial development, institutions and economic growth: Evidence from Sub-Saharan Africa. MPRA Working Paper.

Fafchamps, M., \& Schündeln, M. (2013). Local financial development and firm performance: Evidence from Morocco. Journal of Development Economics, 103, 15-28.

FitzGerald, V. (2006). Financial development and economic growth: a critical view. World Economic and Social Survey, 1-33.

García-Herrero, A., Gavilá, S., \& Santabárbara, D. (2009). What explains the low profitability of Chinese banks? Journal of Banking \& Finance, 33(11), 2080-2092.

Giuliano, P., \& Ruiz-Arranz, M. (2009). Remittances, financial development, and growth. Journal of Development Economics, 90(1), 144-152. 
Guiso, L., Sapienza, P., \& Zingales, L. (2004). Does local financial development matter? The Quarterly Journal of Economics, 119(3), 929-969.

Hajilee, M. \& Nasser, O.M. (2017). Financial depth and exchange rate volatility: A multi-country analysis. The American Economist 62(1), 19-30.

King, R. G., \& Levine, R. (1993). Finance and growth: Schumpeter might be right. The quarterly journal of economics, 108(3), 717-737.

Klein, P. O., \& Weill, L. (2018). Bank profitability and economic growth. University of Strasbourg Working Paper.

Köhler, M. (2014). Does non-interest income make banks more risky? Retail-versus investment-oriented banks. Review of Financial Economics, 23(4), 182-193.

Kumar, V., \& Bird, R. (2021). Factors influencing the profitability of banks in India and China. Applied Economics Letters, 1-5.

Le, T. D., \& Ngo, T. (2020). The determinants of bank profitability: A cross-country analysis. Central Bank Review, 20(2), 65-73.

Lee, C. C., \& Hsieh, M. F. (2013). The impact of bank capital on profitability and risk in Asian banking. Journal of international money and finance, 32, 251-281.

Lee, C. C., Yang, S. J., \& Chang, C. H. (2014). Non-interest income, profitability, and risk in banking industry: A cross-country analysis. The North American Journal of Economics and Finance, 27, 48-67.

Levine, R. (1997). Financial development and economic growth: Views and agenda. Journal of Economic Literature 35, 688-726.

Levine, R. (2005). Finance and growth: Theory and Evidence. https://ideas.repec.org/h/eee/grochp/112.html

Mesagan, E., Olunkwa, N., \& Yusuf, I. (2018). Financial development and manufacturing performance: The Nigerian case. Studies in Business and Economics, 13(1), 97-111.

Murinde, V. (2012). Financial development and economic growth: Global and African evidence. Journal of African Economies, 21(suppl 1), i10-i56.

Nourzad, F. (2002). Financial development and productive efficiency: A panel study of developed and developing countries. Journal of Economics and Finance, 26(2), 138-148. 
Oino, I. (2015). Competitiveness and determinants of bank profitability in Sub-Saharan Africa. International Journal of Economics and Finance, 7(10), 151-162.

Olson, D., \& Zoubi, T. A. (2011). Efficiency and bank profitability in MENA countries. Emerging markets review, 12(2), 94-110.

Ozili, P. K. (2015). Determinants of bank profitability and basel capital regulation: Empirical evidence from Nigeria. Research Journal of Finance and Accounting, 6(2), 124-131.

Ozili, P. K. (2017a). Bank profitability and capital regulation: evidence from listed and non-listed banks in Africa. Journal of African Business, 18(2), 143-168.

Ozili, P. K. (2017b). Bank income smoothing and loan loss provisioning practices in Africa. Doctoral dissertation, University of Essex.

Ozili, P. K., \& Outa, E. (2017). Bank loan loss provisions research: A review. Borsa Istanbul Review, 17(3), 144-163.

Ozili, P. K. (2018a). Banking stability determinants in Africa. International Journal of Managerial Finance, 14(4), 462-483.

Ozili, P. K. (2018b). Bank loan loss provisions, investor protection and the macroeconomy. International Journal of Emerging Markets, 13(1), 45-65.

Ozili, P. K., \& Uadiale, O. (2017). Ownership concentration and bank profitability. Future Business Journal, 3(2), 159-171.

Ozili, P. K. (2019). Non-performing loans and financial development: new evidence. The Journal of Risk Finance, 20(1), 59-81.

Ozili, P. K. (2021). Bank profitability determinants: comparing the United States, Nigeria and South Africa. International Journal of Banking and Finance, 16(1), 55-78.

Peterson, O. K., \& Arun, T. G. (2018). Income smoothing among European systemic and non-systemic banks. The British Accounting Review, 50(5), 539-558.

Smith, R., Staikouras, C., \& Wood, G. (2003). Non-interest income and total income stability. Bank of England Working Paper No. 198, Cass Business School Research Paper.

Tan, Y., \& Floros, C. (2012). Bank profitability and inflation: the case of China. Journal of Economic Studies, 39(6), 675-696. 
Ting, H. I. (2017). Financial development, role of government, and bank profitability: evidence from the 2008 financial crisis. Journal of Economics and Finance, 41(2), 370-391.

Valverde, S. C., \& Fernández, F. R. (2007). The determinants of bank margins in European banking. Journal of Banking \& Finance, 31(7), 2043-2063.

Williams, B. (2016). The impact of non-interest income on bank risk in Australia. Journal of Banking \& Finance, 73, 16-37.

Zhang, J., Wang, L., \& Wang, S. (2012). Financial development and economic growth: Recent evidence from China. Journal of Comparative Economics, 40(3), 393-412.

Zheng, C., Rahman, M., Begum, M., \& Ashraf, B. (2017). Capital regulation, the cost of financial intermediation and bank profitability: evidence from Bangladesh. Journal of Risk and Financial Management, 10(2), 9. 


\section{APPENDIX}

\section{Appendix 1}

\begin{tabular}{|c|c|c|c|}
\hline \multicolumn{4}{|c|}{ Appendix 1: Variable definition, description and source } \\
\hline $\begin{array}{l}\text { Variabl } \\
\text { es }\end{array}$ & Indicator Name & Description & Source \\
\hline FD & $\begin{array}{l}\text { Financial system } \\
\text { deposits to GDP }(\%)\end{array}$ & $\begin{array}{l}\text { Demand, time and saving deposits in } \\
\text { deposit money banks and other financial } \\
\text { institutions as a share of GDP }\end{array}$ & $\begin{array}{l}\text { Global Financial development } \\
\text { indicators World Bank database }\end{array}$ \\
\hline $\mathrm{CD}$ & $\begin{array}{l}\text { Domestic credit to } \\
\text { private sector (\% of } \\
\text { GDP) }\end{array}$ & $\begin{array}{l}\text { Domestic credit to private sector refers to } \\
\text { financial resources provided to the private } \\
\text { sector, such as through loans, purchases of } \\
\text { non-equity securities, and trade credits and } \\
\text { other accounts receivable, that establish a } \\
\text { claim for repayment. }\end{array}$ & $\begin{array}{l}\text { World Development Indicators } \\
\text { (WDI), World Bank }\end{array}$ \\
\hline CAR & $\begin{array}{l}\text { Bank regulatory } \\
\text { capital to risk- } \\
\text { weighted assets }(\%)\end{array}$ & $\begin{array}{l}\text { Measured as the ratio of a bank's core tier } \\
1 \text { capital to its total risk-weighted assets. }\end{array}$ & $\begin{array}{l}\text { Global Financial development } \\
\text { indicators World Bank database }\end{array}$ \\
\hline NPL & $\begin{array}{l}\text { Bank nonperforming } \\
\text { loans to gross loans } \\
(\%)\end{array}$ & $\begin{array}{l}\text { Measured as nonperforming loans divided } \\
\text { by gross loan }\end{array}$ & $\begin{array}{l}\text { Global Financial development } \\
\text { indicators World Bank database }\end{array}$ \\
\hline NII & $\begin{array}{l}\text { Bank noninterest } \\
\text { income to total } \\
\text { income }(\%)\end{array}$ & $\begin{array}{l}\text { Total fee income (including commission } \\
\text { and other non-interest income) divided by } \\
\text { total income }\end{array}$ & Bankscope \\
\hline NIM & $\begin{array}{l}\text { Bank net interest } \\
\text { margin }(\%)\end{array}$ & $\begin{array}{l}\text { Net interest margin (NIM) is the difference } \\
\text { between the interest income generated by } \\
\text { banks or other financial institutions and the } \\
\text { amount of interest paid out to their lenders } \\
\text { (for example, deposits), divided by to the } \\
\text { amount of their (interest-earning) assets. }\end{array}$ & Bankscope \\
\hline LD & $\begin{array}{l}\text { Bank lending-deposit } \\
\text { spread }\end{array}$ & $\begin{array}{l}\text { Difference between lending rate and } \\
\text { deposit rate. }\end{array}$ & $\begin{array}{l}\text { Global Financial development } \\
\text { indicators World Bank database }\end{array}$ \\
\hline EFF & $\begin{array}{l}\text { Bank cost to income } \\
\text { ratio }(\%)\end{array}$ & $\begin{array}{l}\text { It shows a bank's costs in relation to its } \\
\text { income. It is measured as total operating } \\
\text { costs (administrative and fixed costs, such } \\
\text { as salaries and property expenses, but not } \\
\text { bad debts that have been written off) } \\
\text { divided by operating income. }\end{array}$ & Bankscope \\
\hline $\mathrm{CN}$ & $\begin{array}{l}\text { Bank concentration } \\
(\%)\end{array}$ & $\begin{array}{l}\text { the ratio of the combined market shares of } \\
\text { a given number of firms to the whole } \\
\text { market size }\end{array}$ & Bankscope \\
\hline
\end{tabular}


Appendix 2

Variance Inflation Factors (NIM dependent variable)

Date: 10/24/21 Time: 06:38

Sample: 19962016

Included observations: 17

\begin{tabular}{cccc}
\hline \hline Variable & $\begin{array}{c}\text { Coefficient } \\
\text { Variance }\end{array}$ & $\begin{array}{c}\text { Uncentered } \\
\text { VIF }\end{array}$ & $\begin{array}{c}\text { Centered } \\
\text { VIF }\end{array}$ \\
\hline \hline C & 39.90456 & 283.6984 & NA \\
CAR & 0.015576 & 31.10180 & 3.135527 \\
CD & 0.153071 & 164.2696 & 15.81840 \\
CN & 0.003795 & 44.76268 & 4.685276 \\
EFF & 0.006943 & 198.6717 & 2.607498 \\
FD & 0.101181 & 149.4244 & 13.24642 \\
GDP & 0.015431 & 5.160435 & 1.441420 \\
INF & 0.016322 & 16.21225 & 1.433598 \\
NPL & 0.007812 & 17.82935 & 5.082190 \\
\hline \hline
\end{tabular}

Appendix 3

Variance Inflation Factors (NII dependent variables)

Date: 10/24/21 Time: 06:36

Sample: 19962016

Included observations: 17

\begin{tabular}{cccc}
\hline \hline Variable & $\begin{array}{c}\text { Coefficient } \\
\text { Variance }\end{array}$ & $\begin{array}{c}\text { Uncentered } \\
\text { VIF }\end{array}$ & $\begin{array}{c}\text { Centered } \\
\text { VIF }\end{array}$ \\
\hline \hline C & 82.58568 & 283.6984 & NA \\
CAR & 0.032236 & 31.10180 & 3.135527 \\
CD & 0.316792 & 164.2696 & 15.81840 \\
CN & 0.007855 & 44.76268 & 4.685276 \\
EFF & 0.014370 & 198.6717 & 2.607498 \\
FD & 0.209402 & 149.4244 & 13.24642 \\
GDP & 0.031937 & 5.160435 & 1.441420 \\
INF & 0.033779 & 16.21225 & 1.433598 \\
NPL & 0.016167 & 17.82935 & 5.082190 \\
\hline \hline
\end{tabular}


Appendix 4

Variance Inflation Factors (LD dependent variable)

Date: 10/24/21 Time: 06:36

Sample: 19962016

Included observations: 17

\begin{tabular}{cccc}
\hline \hline Variable & $\begin{array}{c}\text { Coefficient } \\
\text { Variance }\end{array}$ & $\begin{array}{c}\text { Uncentered } \\
\text { VIF }\end{array}$ & $\begin{array}{c}\text { Centered } \\
\text { VIF }\end{array}$ \\
\hline \hline C & 49.36508 & 283.6984 & NA \\
CAR & 0.019269 & 31.10180 & 3.135527 \\
CD & 0.189360 & 164.2696 & 15.81840 \\
CN & 0.004695 & 44.76268 & 4.685276 \\
EFF & 0.008589 & 198.6717 & 2.607498 \\
FD & 0.125169 & 149.4244 & 13.24642 \\
GDP & 0.019090 & 5.160435 & 1.441420 \\
INF & 0.020191 & 16.21225 & 1.433598 \\
NPL & 0.009664 & 17.82935 & 5.082190 \\
\hline \hline
\end{tabular}

Appendix 5

Variance Inflation Factors (ROA dependent variable)

Date: 10/24/21 Time: 06:35

Sample: 19962016

Included observations: 17

\begin{tabular}{cccc}
\hline \hline Variable & $\begin{array}{c}\text { Coefficient } \\
\text { Variance }\end{array}$ & $\begin{array}{c}\text { Uncentered } \\
\text { VIF }\end{array}$ & $\begin{array}{c}\text { Centered } \\
\text { VIF }\end{array}$ \\
\hline \hline C & 66.63232 & 283.6984 & NA \\
CAR & 0.026009 & 31.10180 & 3.135527 \\
CD & 0.255596 & 164.2696 & 15.81840 \\
CN & 0.006337 & 44.76268 & 4.685276 \\
EFF & 0.011594 & 198.6717 & 2.607498 \\
FD & 0.168951 & 149.4244 & 13.24642 \\
GDP & 0.025767 & 5.160435 & 1.441420 \\
INF & 0.027254 & 16.21225 & 1.433598 \\
NPL & 0.013044 & 17.82935 & 5.082190 \\
\hline \hline
\end{tabular}


Appendix 6

Variance Inflation Factors (ROE dependent variable)

Date: 10/24/21 Time: 06:33

Sample: 19962016

Included observations: 17

\begin{tabular}{cccc}
\hline \hline Variable & $\begin{array}{c}\text { Coefficient } \\
\text { Variance }\end{array}$ & $\begin{array}{c}\text { Uncentered } \\
\text { VIF }\end{array}$ & $\begin{array}{c}\text { Centered } \\
\text { VIF }\end{array}$ \\
\hline \hline C & 839.8365 & 283.6984 & NA \\
CAR & 0.327818 & 31.10180 & 3.135527 \\
CD & 3.221543 & 164.2696 & 15.81840 \\
CN & 0.079875 & 44.76268 & 4.685276 \\
EFF & 0.146129 & 198.6717 & 2.607498 \\
FD & 2.129470 & 149.4244 & 13.24642 \\
GDP & 0.324771 & 5.160435 & 1.441420 \\
INF & 0.343505 & 16.21225 & 1.433598 \\
NPL & 0.164411 & 17.82935 & 5.082190 \\
\hline \hline
\end{tabular}

